\title{
Eastern Andean environmental and climate synthesis for the last 2000 years BP from terrestrial pollen and charcoal records of Patagonia
}

G. D. Sottile ${ }^{1}$, M. E. Echeverria ${ }^{1}$, M. V. Mancini ${ }^{1}$, M. M. Bianchi ${ }^{2,3}$, M. A. Marcos ${ }^{1}$, and F. P. Bamonte ${ }^{1}$

${ }^{1}$ Laboratorio de Paleoecología y Palinología, Departamento de Biología, Facultad de Ciencias Exactas y Naturales, UNMDP-IIMyC-CONICET, Funes 3250, 7600, Mar del Plata, Argentina ${ }^{2}$ CONICET, Instituto Nacional de Antropología y Pensamiento Latinoamericano (INAPL), Buenos Aires, Argentina

${ }^{3}$ Museo Argentino de Ciencias Naturales (MACN), Buenos Aires, Argentina

Received: 1 April 2015 - Accepted: 6 May 2015 - Published: 3 June 2015

Correspondence to: G. D. Sottile (gonzalo_sottile@yahoo.com.ar)

Published by Copernicus Publications on behalf of the European Geosciences Union.

Eastern Andean environmental synthesis for the last 2000 years of

Patagonia

G. D. Sottile et al.

\section{Title Page}

Abstract Introduction

Conclusions References

Tables Figures

14 4

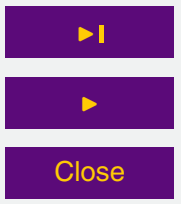

Full Screen / Esc

Printer-friendly Version

Interactive Discussion 


\section{Abstract}

The Southern Hemisphere Westerly Winds (SWW) constitute an important zonal circulation system that dominates the dynamics of Southern Hemisphere mid-latitude climate. Little is known about climatic changes in the Southern South America in 5 comparison to the Northern Hemisphere due to the low density of proxy records, and adequate chronology and sampling resolution to address environmental changes of the last 2000 years. Since 2009, new pollen and charcoal records from bog and lakes in northern and southern Patagonia at the east side of the Andes have been published with an adequate calibration of pollen assemblages related to modern 10 vegetation and ecological behaviour. In this work we improve the chronological control of some eastern Andean previously published sequences and integrate pollen and charcoal dataset available east of the Andes to interpret possible environmental and SWW variability at centennial time scales. Through the analysis of modern and past hydric balance dynamics we compare these scenarios with other western

15 Andean SWW sensitive proxy records for the last 2000 years. Due to the distinct precipitation regimes that exist between Northern $\left(40-45^{\circ} \mathrm{S}\right)$ and Southern Patagonia $\left(48-52^{\circ} \mathrm{S}\right)$ pollen sites locations, shifts on latitudinal and strength of the SWW results in large changes on hydric availability on forest and steppe communities. Therefore, we can interpret fossil pollen dataset as changes on paleohydric balance at every single site by the construction of paleohydric indices and comparison to charcoal records during the last 2000 calyrs BP. Our composite pollen-based Northern and Southern Patagonia indices can be interpreted as changes in latitudinal variation and intensity of the SWW respectively. Dataset integration suggest poleward SWW between 2000 and 750 calyrs BP and northward-weaker SWW during the Little Ice 25 Age (750-200 calyrs BP). These SWW variations are synchronous to Patagonian fire activity major shifts. We found an in phase fire regime (in terms of timing of biomass burning) between northern Patagonia Monte shrubland and Southern Patagonia steppe environments. Conversely, there is an antiphase fire regime between

\section{CPD}

$11,2121-2157,2015$

\section{Eastern Andean environmental synthesis for the last 2000 years of Patagonia}

G. D. Sottile et al.

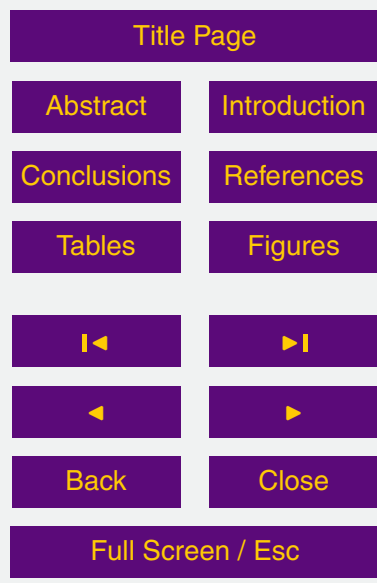

Printer-friendly Version

Interactive Discussion 
Northern and Southern Patagonia forest and forest-steppe ecotone environments. SWW variability may be associated to ENSO variability especially during the last millennia. For the last 200 cal yrs BP we can concluded that the SWW belt were more intense and poleward than the previous interval. Our composite pollen-based SWW 5 indices show the potential of pollen dataset integration to improve the understanding of paleohydric variability especially for the last 2000 millennial in Patagonia.

\section{Introduction}

The Southern Hemisphere Westerly Winds (SWW) constitute an important zonal circulation system that dominates the dynamics of Southern Hemisphere mid-latitude climate. Furthermore, they influence the global ocean circulation through wind-driven upwelling of deep water in the Southern Ocean and may play a significant role in the global climate system through the control of the $\mathrm{CO}_{2}$ budget in the Southern Ocean (Anderson et al., 2009; Toggweiler et al., 2006; Varma et al., 2011). The understanding of the variability and the impact of various forcings on the SWW has been discussed by the study of different proxy and modelling approaches especially at millennial time scales during the Holocene (e.g. Fletcher and Moreno, 2011; Kilian and Lamy, 2012; Lamy et al., 2001, 2010; Varma et al., 2012; Whitlock et al., 2007). Little, however, is known about climatic changes in the Southern Hemisphere in comparison to the Northern Hemisphere due to the low density of proxy records, and adequate chronology and sampling resolution to address environmental changes of the last 2000 years (Moy et al., 2009; Villalba et al., 2009). Nevertheless, the few available records point towards significant fluctuations in both temperature and precipitation occurring during this period (Jones and Mann, 2004; Masiokas et al., 2009; Tonello et al., 2009). On this time scale orbital boundary conditions only changed slightly and humans became noticeable (Jones and Mann, 2004; Wilmes et al., 2012).

\section{CPD}

$11,2121-2157,2015$

\section{Eastern Andean environmental synthesis for the last 2000 years of Patagonia}

G. D. Sottile et al.

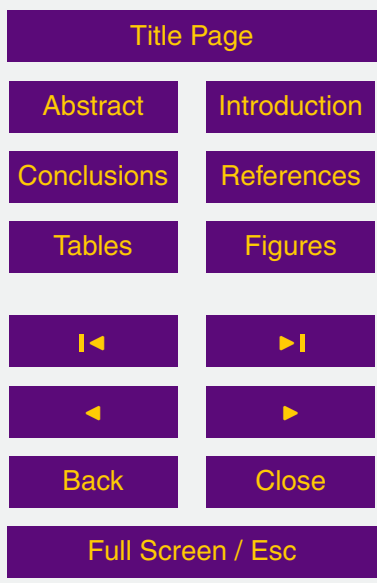

Printer-friendly Version

Interactive Discussion 
The "Little Ice Age" (LIA) usually refers to climatic anomalies over the Northern Hemisphere between the 13th and mid-19th century (750-150 calyrsBP). The LIA is well documented in northern Europe and North America, where a huge variety of chronicles, historical documents, proxy-based reconstructions and also temperature 5 measurements indicate cooler and wetter conditions (Meyer and Wagner, 2008). Within LIA, a period with even lower temperatures was the Maunder Minimum (MM; AD 1645-1715/305-235 cal yrs BP). Proxy and modelling studies point to a prominent influence of solar forcing causing the MM (Eddy, 1976; Zorita et al., 2004). At the beginning of the last millennium, a period of warmer conditions, especially over 10 Europe, has been documented: the so-called Medieval Warm Period (MWP; ca 9th13th centuries/1150-750 calyrsBP; Jones et al., 2001; Osborn and Briffa, 2006). Recently, Neukom et al. $(2010,2011,2014)$ points to a number of climatic variations occurring during the last millennium in Southern South America. The authors showed that the Southern Hemisphere response to external forcing may be delayed in 15 approximately two centuries respect to Northern Hemisphere medieval times with high temperatures and coherent extreme cool conditions in both hemispheres around AD 1600 (350 cal yrs BP).

Pollen records derived from lakes and bogs represent one of the most abundant paleoclimate archives in South America. Since the pioneering work by Auer (1933, 20 1958), many studies have reconstructed the ecological and climatic history over the Pleistocene and Holocene periods at millennial time scale (e.g. Heusser and Heusser, 2006; Mancini et al., 2008; Markgraf et al., 2003; Moreno et al., 2009). There are few pollen based paleoenvironmental reconstruction with highly-precise chronology in Patagonia for the last millennia (Fletcher and Moreno, 2012b; Huber and Markgraf, 2003a; Moreno et al., 2014; Whitlock et al., 2006; Wille et al., 2007). These authors presented different Patagonia climatic variability scenarios for the last 2000 years. Moy et al. (2009) and Kilian and Lamy (2012) suggest that the different signal shown in these data set could be attributed to the location of the records in different ecological

\section{CPD}

11, 2121-2157, 2015

\section{Eastern Andean environmental synthesis for the last 2000 years of Patagonia}

G. D. Sottile et al.

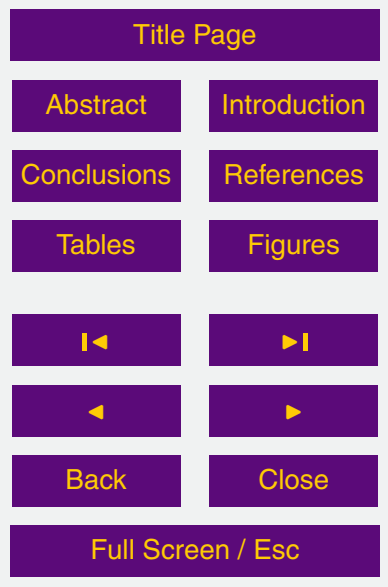

Printer-friendly Version

Interactive Discussion 
environments; the depositional environment, and local differences in the sensitivity of eastern Andean vegetation ecotones to changes in precipitation.

Since 2009, new pollen and charcoal records from bog and lakes in northern and southern Patagonia at the east side of the Andes have been published with 5 an adequate calibration of pollen assemblages related to modern vegetation and ecological behaviour (Bamonte and Mancini, 2011; Bamonte et al., 2014; Echeverria et al., 2014; Iglesias, 2013; Iglesias and Whitlock, 2014; Iglesias et al., 2012, 2014; Mancini, 2009; Marcos et al., 2012a, b; Sottile et al., 2012; Sottile, 2014). In this work we improve the chronological control of some eastern Andean previously published 10 sequences and integrate pollen and charcoal dataset available east of the Andes to interpret possible environmental and SWW variability at centennial time scales. Through the analysis of modern and past hydric balance dynamics we compare these scenarios with other western Andean SWW sensitive proxy records for the last 2000 years.

\section{Modern eastern Andean Patagonia environmental setting}

\subsection{Climate}

Most of Patagonia is dominated by air masses coming from the Pacific Ocean. The Patagonian region is located between the semipermanent anticyclones of the Pacific and the Atlantic oceans at approximately $30^{\circ} \mathrm{S}$ and the subpolar low pressure belt at approximately $60^{\circ} \mathrm{S}$ (Prohaska, 1976). The strong, constant west winds (westerlies) are dominant across the region. The seasonal movement of the low and high pressure systems and the equatorward ocean currents determine the precipitation pattern. During winter, the subpolar low is more intense. This situation, combined with the equatorial displacement of the Pacific High Pressure System and with ocean temperatures that are higher than the continental temperatures, leads to an increase in precipitation during this season. The northeastern and the southeastern parts of the
CPD

11, 2121-2157, 2015

Eastern Andean environmental synthesis for the last 2000 years of Patagonia

G. D. Sottile et al.

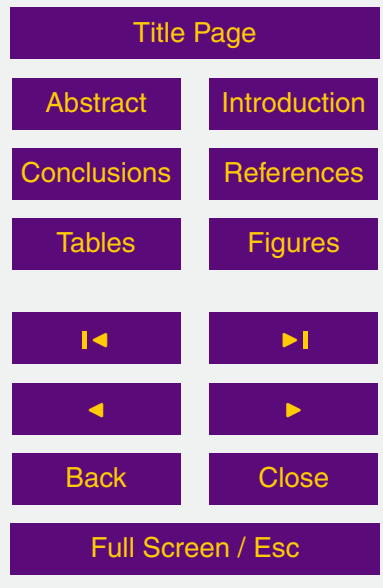

Printer-friendly Version

Interactive Discussion 
region are additionally affected by air masses coming from the Atlantic Ocean. This Atlantic influence results in a more even seasonal distribution of precipitation in this part of Patagonia (Paruelo et al., 1998).

The Andes play a crucial role in determining the climate of Patagonia. The north5 south distribution of the mountains imposes an important barrier for humid air masses coming from the Pacific Ocean. Most of the water in these maritime air masses is dropped on the Chilean side, and air becomes hotter and drier through adiabatic warming as it descends on the Argentine side of the Andes (Fig. 1a). The westerlies are strongest during austral summer, peaking between 45 and $55^{\circ} \mathrm{S}$. During austral 10 winter, the jet stream moves into subtropical latitudes (its axis is about $30^{\circ} \mathrm{S}$ ) and the low-level westerlies expand equatorward but weaken, particularly at $\sim 50^{\circ} \mathrm{S}$ (Garreaud et al., 2009) (Fig. 1b).

Over Patagonia, the inter-annual correlation between precipitation and zonal wind at $850 \mathrm{hPa}$ (U850) using annual means exhibits positive values increasing from Pacific to 15 a maximum along the Chilean coast and the western slope of the Andes $(r(P, \mathrm{U} 850) \sim$ 0.8 ), a sharp transition just to the east of the mountain ridge and negative values over the Argentinean Patagonia. During years with stronger than average westerly flow features increased precipitation to the west of the Andes and decreased precipitation over the lowlands to the east. The marked west-east precipitation gradient over 20 Patagonia is always present but it is slightly less in those years with weaker than average westerly flow aloft (Garreaud et al., 2013).

When averaged over the year, an ENSO warm event (positive multivariate ENSO index values) is associated with an overall decrease in the strength of the wind field and a slight reduction in precipitation in western Patagonia (Moy et al., 2009). 25 Northern Patagonia exhibits an overall reduction in summer precipitation and warmer surface air temperature. Of particular relevance is the frequent occurrence of longlived, tropospheric deep anticyclonic anomalies west of the southern tip of South America (below $40^{\circ} \mathrm{S}$ and centered at $50^{\circ} \mathrm{S}, 100^{\circ} \mathrm{W}$ ) during El Niño years (Rutllant and Fuenzalida, 1991). These phenomena favour a northward displacement of the

\section{CPD}

$11,2121-2157,2015$

\section{Eastern Andean environmental synthesis for the last 2000 years of Patagonia}

G. D. Sottile et al.

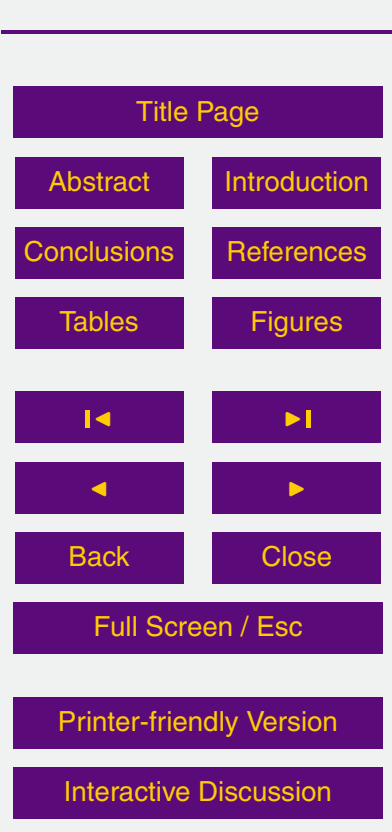

2126 
storm tracks between 33 and $39^{\circ} \mathrm{S}$ (Garreaud and Aceituno, 2007; Garreaud et al., 2009; Montecinos et al., 2000; Moreno et al., 2010). During negative multivariate ENSO index values (La Niña like), the South Pacific anticyclone strengthen and moves southward (Aceituno, 1988). Similarly, during the positive phase of Southern Annular 5 Mode (SAM), the SWW intensifies and moves southward, decreasing precipitation above $48^{\circ} \mathrm{S}$, favouring the occurrence of forest fires between 39 and $48^{\circ} \mathrm{S}$ (Holz and Veblen, 2011; Mundo et al., 2013; Veblen et al., 1999; Villalba et al., 2012).

\subsection{Northern Patagonia vegetation}

Eastern Andean communities in Northern Patagonia between 40 and $44^{\circ} \mathrm{S}$ present 10 four major transitions. The first $\left(\mathrm{ca} 72^{\circ} \mathrm{W}\right)$ from tree/epiphyte species rich Valdivian rainforest to structurally more simple poor species Nothofagus-dominated forests. This transition zone coincides approximately with eastern areas of low Andean longitudinal valleys and where precipitation drops below ca 3000-2500 $\mathrm{mm} \mathrm{yr}^{-1}$. A second sharp transition occurs further east (ca $71.6^{\circ} \mathrm{W}$ ) where the continuous Nothofagus forest cover breaks up giving rise to first patchy but further east more extensive species rich shrublands composed of heliophyllous species (Iglesias et al., 2014). This transition occurs where annual precipitation drops below ca $1800 \mathrm{mmyr}^{-1}$. Finally, a third transition takes place at ca $71-71.2^{\circ} \mathrm{W}$ where easternmost small outpost trees population (Nothofagus pumilio and Austrocedrus chilensis) intermingle within the Patagonian steppe matrix. This transition coincides with rainfall areas below ca 600 $800 \mathrm{~mm} \mathrm{yr}^{-1}$ (Iglesias et al., 2014). South of $44^{\circ} \mathrm{S}$, Austrocedrus chilensis disappear and only Nothofagus tree patches intermingle between steppe patches (Veblen et al., 1997). Patagonian grass and shrub steppes cover plains and plateaus eastward $\sim 70^{\circ} \mathrm{W}$ between 600 and $300 \mathrm{~mm} \mathrm{yr}^{-1}$, with a significant decrease on above-ground 25 vegetation cover following precipitation gradient (León et al., 1998). Below $300 \mathrm{~mm} \mathrm{yr}^{-1}$, Patagonian steppe is replaced by "Monte" shrubland vegetation (Fig. 1a). Monte shrub communities are arranged as two-phase mosaic composed by a phase of perennial

\section{CPD}

$11,2121-2157,2015$

Eastern Andean environmental synthesis for the last 2000 years of Patagonia

G. D. Sottile et al.

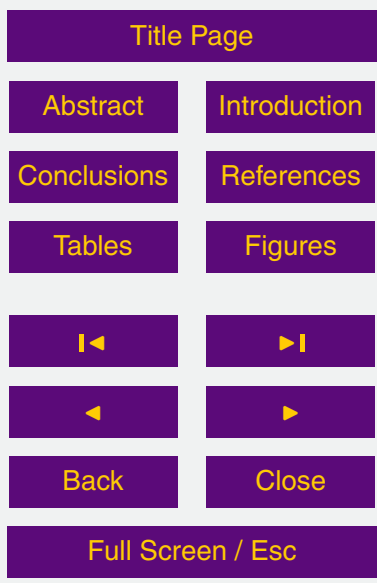

Printer-friendly Version

Interactive Discussion 
grasses and shrub-dominated patches alternating with sparse cover (Bisigato et al., 2009).

\subsection{Southern Patagonia vegetation}

South of $47^{\circ} \mathrm{S}$, the forest communities impoverished due to the low temperatures 5

growing season. Mixed evergreen-deci and $N$. pumilio develop on eastern Andean lowland areas with annual precipitation above $800 \mathrm{mmyr}^{-1}$ (Mancini et al., 2008). Between 1000 and $600 \mathrm{~mm}$ of annual precipitation closed deciduous forest of $N$. pumilio develop from the tree line to lowlands. These closed forest communities become progressively open with tree patches of $N$. pumilio and $N$. antarctica with high cover of tall xerophytic shrubs and grass species between 600 and $400 \mathrm{~mm} \mathrm{yr}^{-1}$. Eastward between 400 and $200 \mathrm{~mm} \mathrm{yr}^{-1}$ a grass steppe covers a narrow and discontinuous strip along the extra-Andean and the Patagonian plateau and the southeastern tip of the continent dominated by Festuca spp., cushions plants and isolated shrub patches (Boelcke et al., 1985; Mancini et al., 2012). At the Patagonian plateau, the shrub steppe distribution is primarily related to the availability of water which is actually controlled by unpredictable precipitation inputs, runoff redistribution and edaphic diversity and is clearly reflected by the vegetation differences between the plateaus and valley and ravines ("cañadones") (Mancini et al., 2012).

\subsection{Fire regime}

The occurrence of wildfires is largely controlled by climatic variability through its action of modifying fine fuel build up rates and fuel desiccation. On the easternmost Patagonian communities where steppe bunchgrasses dominate, fires are limited by fuel amounts and continuity (Kitzberger, 2012; Sottile et al., 2012). Because fine fuels 25 (grasses) are highly responsive to precipitation pulses, during rainy growing seasons, systems that normally do not spread efficiently due to lack of fuel loads suddenly
CPD

$11,2121-2157,2015$

\section{Eastern Andean environmental synthesis for the last 2000 years of Patagonia}

G. D. Sottile et al.

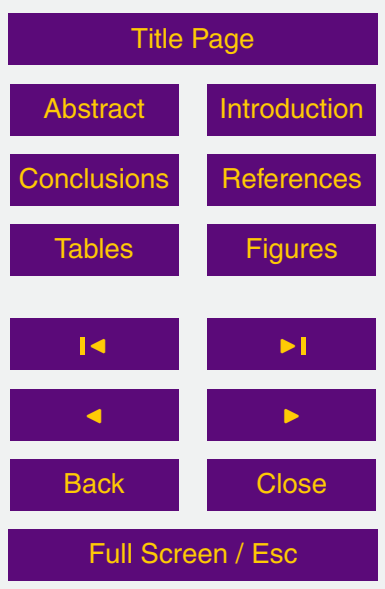

Printer-friendly Version

Interactive Discussion 
become more prone for developing large fires (Morgan et al., 2003). Years with high net primary productivity and rainy springs/summers have also been highlighted as factors favouring fire occurrence in Monte shrubland communities (Hardtke, 2014).

Further west in the transition or higher in altitude, in the realm of the tall Nothofagus 5 forests fine fuels are less important and coarse fuels that require long drying periods dominate. Here fires are exclusively associated to strong droughts lasting several months, beginning during the winter, the time when soils are replenished with water (Kitzberger, 2012). Whenever dry winter-springs associate with warm summers, wet forests ignite and spread fire without significant natural fire breaks (Mermoz et al.,

10 2005). These strong drought events not only produce larger fires but also more severe events that create conditions that provide less regeneration opportunities to obligate seed dispersed species (such as N. dombeyi or N. pumilio; Kitzberger et al., 2005) and more opportunities for the rapid expansion of resprouting shrubland species. Markgraf and Anderson (1994) postulated that even though lightning are scarce in southern 15 Patagonia, they might have been more frequent in the past under different climatic conditions as fire ignition sources.

\section{Material and methods}

In order to reconstruct the past 2000 years of environmental variability on different landscapes of eastern Andean Patagonia, we selected continuous pollen and charcoal 20 records from lakes and peat-bogs (Table 1) where data sets fulfil some qualitative criteria explained as follows:

Dataset availability: pollen records previously published and available at Neotoma Paleoecology Database (http://www.neotomadb.org) and pollen/charcoal records from Paleoecology and Palynology Lab database (UNMdP-IIMyC, CONICET).

25 Chronology and temporal resolution: proxy data series must have a chronology based on more than 2 dating for the last $2300 \mathrm{yrs}$ BP. The time series should at least have a mean sampling resolution of one sample $200 \mathrm{yrs}^{-1}$.

\section{CPD}

$11,2121-2157,2015$

Eastern Andean environmental synthesis for the last 2000 years of Patagonia

G. D. Sottile et al.

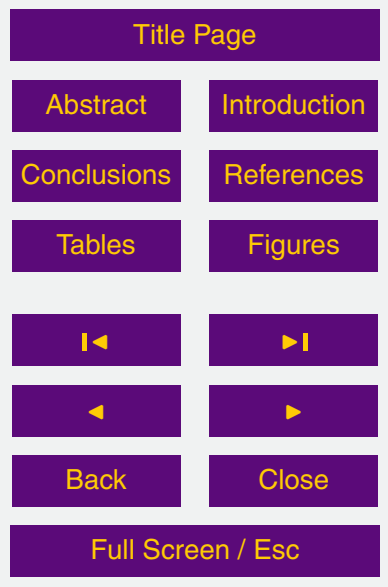

Printer-friendly Version

Interactive Discussion 
Also, the sites selected for this work, fulfil more than four criteria of $2 \mathrm{~K}$ proxy records for paleoclimate reconstructions according to the PAGES-2 K criteria (see Supplement, Sect. 3, for details).

We constructed past pollen-based paleohydric balance indices. Main pollen taxa 5 were considered suggesting above/below hydric availability at every site, following paleoecological and modern pollen-vegetation calibrations highlighted on previous published works (Bamonte and Mancini, 2011; Bamonte et al., 2014; Bianchi and Ariztegui, 2012; Echeverria et al., 2014; Iglesias, 2013; Iglesias and Whitlock, 2014; Iglesias et al., 2012, 2014; Mancini, 2007, 2009; Mancini et al., 2012; Marcos and 10 Mancini, 2012; Marcos et al., 2012a; Paez et al., 2001; Sottile et al., 2012; Sottile, 2014). Each paleohydric balance was calculated as the standardized ratio between the sum (in percentages) of positive hydric availability taxa and the sum of negative hydric availability taxa (see Supplement, Sect. 4 for details). Standarization of every ratio was calculated by subtracting the mean and dividing by the standard deviation. In order to 15 highlight the general trend of every site index, we apply a locally weighted scatterplot 0.2 smoothing spline (Cleveland, 1979, 1981) and plotted the $95 \%$ confidence band based on a 999 bootstrap replicate technique. Modern hydric balance of every site (Table 1) was compared to paleohydric values in reference to the pollen samples with an age of ca AD 1900 of every record (preventing possible changes on pollen spectra related to European settlement).

Also, composite pollen-based indices for Northern and Southern Patagonia were performed using all dataset available for each region. In order to highlight the general positive/negative trends of every region index, we applied a locally weighted 0.2 smoothing spline and plotted the $95 \%$ confidence band based on a 999 bootstrap

\section{CPD}

$11,2121-2157,2015$

\section{Eastern Andean environmental synthesis for the last 2000 years of Patagonia}

G. D. Sottile et al.

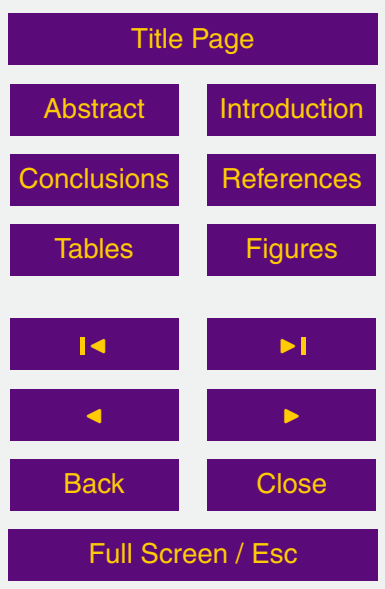

Printer-friendly Version

Interactive Discussion 


\section{Results}

\subsection{Northern Patagonia}

Northern Patagonian pollen based paleohydric balance allow us to reconstruct past variability especially in terms of seasonality. Assuming that Northern Patagonian

5 forest and Monte shrubland development, are favoured by spring-summer rain, positive (negative) values suggest above (below) average spring-summer precipitation. Nothofagus-Austrocedrus forest and Nothofagus forest/steppe transitions records present mainly negative values between 1600 and 750 calyrs BP (Fig. 2b-d). Since 750 calyrs BP, there is a raising trend to positive paleohydric values peaking ca 250 10300 calyrs BP (Fig. 2b-d). On the contrary, Lake Trébol present the opposite trend during the last $2000 \mathrm{yrs}$. The comparison of past paleohydric balance to modern hydric balance suggest $>493.7 \mathrm{~mm} \mathrm{yr}^{-1}$ in Lake Trébol; $<8.60 \mathrm{~mm} \mathrm{yr}^{-1} ;<143.2 \mathrm{~mm} \mathrm{yr}^{-1}$ in Lake Mosquito and <268.4 $\mathrm{mm} \mathrm{yr}^{-1}$ in Mallín Pollux between 1600 and 750 calyrBP.

Even though Bajo de la Quinta shows mainly negative values, its general paleohydric trend follows general forest and forest-steppe transition records behaviour, showing the major paleohydric values after $750 \mathrm{yrs}$ BP (Fig. 2e). A comparison with modern hydric balance values, suggests Bajo de la Quinta registered paleohydric values < $-516.3 \mathrm{~mm} \mathrm{yr}^{-1}$ between 1600 and 750 cal yrs BP.

Fire activity presents an opposite behaviour between Andean communities and 20 Monte shrubland. The highest Charcoal accumulation rates (CHAR) are registered between 2000 and 750 calyrs BP in Andean sites while the highest CHAR values in Bajo de la Quinta occur after 500 calyrsBP. Mallín Pollux and Bajo de la Quinta also register high CHAR values for the last 100 years, which might be related to European settlements.

\section{CPD}

11, 2121-2157, 2015

\section{Eastern Andean environmental synthesis for the last 2000 years of Patagonia}

G. D. Sottile et al.

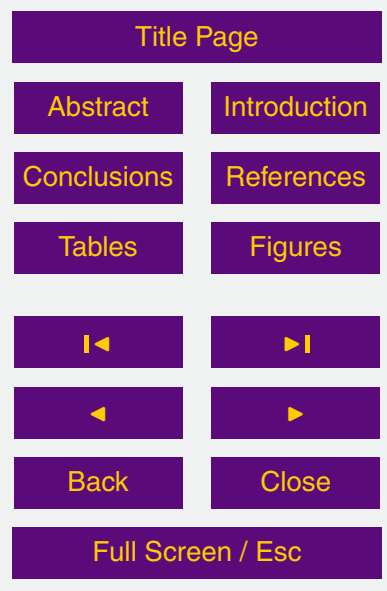

Printer-friendly Version

Interactive Discussion 


\subsection{Southern Patagonia}

Southern Patagonian pollen dataset were classified into two categories (local and regional, sensu Jacobson and Bradshaw, 1981) in response to the pollen source area and the variables selected to calculate past paleohydric balance index. Local dataset 5 category involves pollen records that register past local vegetation variations. These records present a high relationship between surrounding deposition site vegetation pollen indicators and modern pollen samples assemblages (PAA, PAB, MPD, LT, CV). Thus interpretation of the paleohydric balance index from this sites may be related to changes on local conditions. Regional category includes records that on recent 10 pollen samples present higher amounts of pollen types reaching from longer distances ( $>3 \mathrm{~km}$ southwestward) than pollen from surrounding areas of the deposition site (CF and $R R$ ). Thus, we interpret regional paleohydric balance indices not as changes on hydric balance in a single site but throughout the forest-steppe ecotone region.

Southern Patagonian Forest and Forest-steppe ecotone paleohydric indices present 15 positive values between 2000 and 750 calyrs BP, suggesting above average water availability on Andean communities (Fig. 3). On the contrary steppe records present mainly negative values suggesting dry conditions on extra-andean areas (Fig. 3).

Comparison with modern hydric balance values for pollen records registering local environmental variability, suggest higher than modern hydric balance values for PAA, PAB (> 104.5 and $67.2 \mathrm{mmyr}^{-1}$, respectively) previous to 750 calyrBP. Steppe sites suggest values similar to modern ones in MPD $\left(\sim-163.2 \mathrm{mmyr}^{-1}\right)$, higher than modern values in LT $\left(>-146.6 \mathrm{mmyr}^{-1}\right)$ and lower than modern values in CV $(<$ $-303.7 \mathrm{~mm} \mathrm{yr}^{-1}$ ).

After 750 calyrsBP, Forest and forest-steppe sites exhibit a decreasing trend in 25 paleohydric balance indices (Fig. 3). PAA and PAB indices suggest paleohydric values $<104.5$ and $<67.2 \mathrm{~mm} \mathrm{yr}^{-1}$, respectively. Steppe sites exhibit the opposite paleohydric trend toward positive values. The three steppe sites suggest significant higher than present values of hydric balance (MPD > $163.2 \mathrm{mmyr}^{-1}$; LT $>146.6 \mathrm{mmyr}^{-1}$; CV >

\section{CPD}

$11,2121-2157,2015$

Eastern Andean environmental synthesis for the last 2000 years of Patagonia

G. D. Sottile et al.

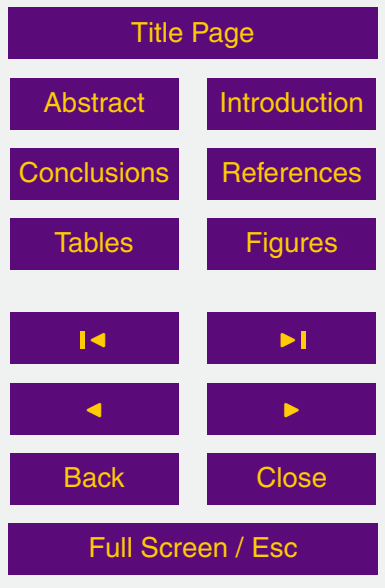

Printer-friendly Version

Interactive Discussion 
$-303.3 \mathrm{~mm} \mathrm{yr}^{-1}$ ). Fire activity exhibit synchronous CHAR patterns especially between 2000-1700 and 750-250 cal yrs BP in southern Patagonian charcoal records.

\section{Discussion}

\subsection{Controls over hydric balance in Northern and Southern Patagonia}

5 The late Holocene changes in paleohydric balance reconstructed from Northern Patagonian records could be interpreted in terms of latitudinal variation of the SWW belt, using the modern latitudinal distribution of precipitation seasonality over Patagonia (Fig. 1b) as analogous. Thus, when modelling all Northern Patagonian dataset we perform a composite pollen-based Northern Patagonia SWW belt latitudinal variation index between 40 and $45^{\circ} \mathrm{S}$ (Fig. 4c). This pollen-based index displays high precipitation seasonality before 750 cal yrs BP. Such a high seasonality likely suggests a more poleward position of the SWW belt, reflecting similar to present day precipitation seasonality (Fig. 4). Nevertheless, Lake Trébol shows high values of paleohydric balance index before 750 calyrs BP and lower values since 750 , around present day paleohydric balance indices, may reflect intense SWW during winter favouring higher precipitation amounts over areas close to the Andean divide linked to a steeper west-to east precipitation gradient that soften up to present condition since 750 calyrs BP.

Since 750 cal yrs BP the Northern Patagonia pollen based index shows a remarkable decrease in precipitation seasonality peaking between 400 and 200 cal yrs BP (Fig. 4c). This low seasonality period likely reflects a northward expansion of the SWW favouring increased spring-summer precipitation near the Andes. The similar paleohydric balance of Bajo de la Quinta (Fig. 2e) at the Atlantic coast to those of forest environments suggest that between 400 and 200 cal yrs BP, Atlantic humid air masses

reached the continent probably under weak SWW (Marcos et al., 2012a, 2014). Therefore we can interpret dominant summer-like conditions in terms of hydric balance

\section{CPD}

$11,2121-2157,2015$

Eastern Andean environmental synthesis for the last 2000 years of Patagonia

G. D. Sottile et al.

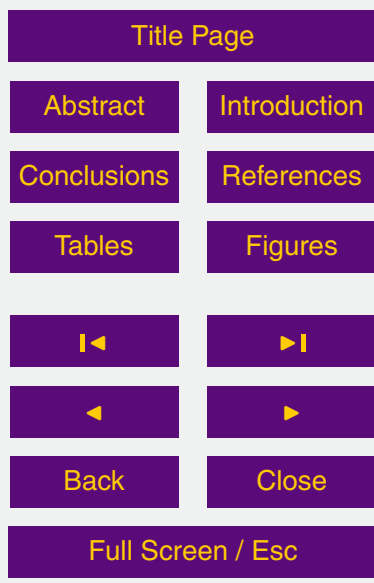

Printer-friendly Version

Interactive Discussion 
in northern Patagonia between 1600 and 750 calyrs BP and winter-like conditions between 750 and 200 cal yrs BP.

During the last 200 calyrs BP, there is a remarkable decrease in the Northern Patagonia pollen based index suggesting higher than before precipitation seasonality 5 toward present day conditions between 40 and $45^{\circ} \mathrm{S}$. Even though pollen spectra might be biased for the last 100 years, the decreasing trend in Northern Patagonia pollen based index, precedes European arrival (Fig. 4c).

Precipitation seasonality inferences coincide with centennial fire activity in northern Patagonia. We found an antiphase behaviour of fire occurrence between western 10 and eastward environments. During southward displacement of SWW, fire activity increases on forest communities likely related to coarse fuel desiccation and low biomass availability on eastern Monte shrublands avoiding fire propagation (Fig. 2e). On the contrary, during periods of winter-like conditions, fire activity increases on Monte shrublands, likely related to an increase in biomass favoured by Atlantic Humid air flow masses. Iglesias and Whitlock (2014) presented northern Patagonia biomass burning general trends since the last 18000 calyrs BP and compared them to environmental and archaeological information. They interpret that variations in indigenous population densities were not associated with fluctuations in regional or watershed-scale fire occurrence, suggesting that climate-vegetation-fire linkages in northern Patagonia evolved with minimal or very localized human influences before European Settlement (Iglesias and Whitlock, 2014). On the Atlantic coast, archaeological records suggest high anthropogenic activity ca 1000 calyrs BP with a decreasing trend up to present day (Marcos and Ortega, 2014). Thus, patterns of fire activity increase since ca 500 calyrs BP in Bajo de la Quinta are likely related to climate variability and lightning 25 sources.

The late Holocene changes in paleohydric balance reconstructed from Southern Patagonian records could be interpreted in terms of intensity variation of the SWW belt, using the modern latitudinal distribution of precipitation seasonality over Patagonia (Fig. 1b) as analogous. These sequences are not significantly affected by seasonal

\section{CPD}

$11,2121-2157,2015$

\section{Eastern Andean environmental synthesis for the last 2000 years of Patagonia}

G. D. Sottile et al.

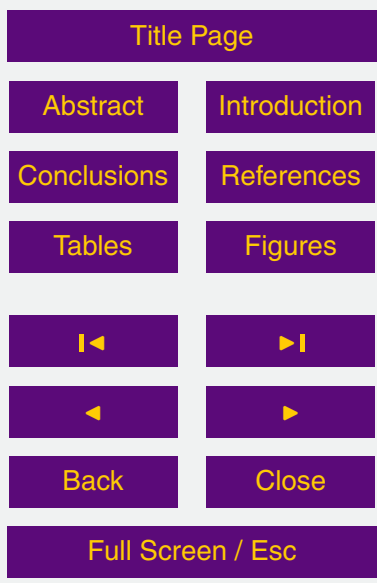

Printer-friendly Version

Interactive Discussion 
variability but mainly affected by changes on SWW intensity (Garreaud et al., 2013). During years with stronger than average SWW precipitation increased to the west of the Andes and decreased over the lowlands to the east (Garreaud et al., 2013). Therefore we expect that hydric balance increases in forest areas (especially those with present 5 day positive hydric balance values) and decreases in grass steppe extra-Andean environments. Conversely, the marked west-east precipitation gradient is slightly less in those years with weaker than average westerly flow, thus we expect lower than average hydric balance values on forest areas and higher than average hydric balance values in grass steppe extra-Andean environments. Atlantic humid air masses probably 10 increase hydric balance values on steppe records next to the Atlantic coast during periods of weaker westerlies (Agosta et al., 2015).

Thus, when modelling all Southern Patagonian datasets we perform a composite pollen-based Southern Patagonia SWW intensity variation index between 48 and $52^{\circ} \mathrm{S}$ (Fig. 4) by considering forest and forest-steppe ecotone index values and inverse 15 steppe index values. Figure 4 shows the scatterplot dataset and smothering spline of Local and Regional records from southern Patagonia. This pollen-based index displays intense SWW before 750 cal yrs BP and weaker SWW since 750 calyrs BP, peaking ca 500-600 calyrs BP (Fig. 4). The Southern Patagonia index increases slightly toward ca 250-300 cal yrs BP suggesting an intensification pulse of the SWW. Since then, the

20 Southern Patagonia index values decreases to modern ones, thus we interpret a slight weakening of the SWW up to modern conditions.

In contrast to Northern Patagonia regional fire behaviour, Southern Patagonia fire activity trends on forest and steppe communities are synchronous. The maximum fire activity in southern Patagonia occurs during weaker westerlies (on steppe environments especially previous to $1600 \mathrm{cal}$ yrs BP, Fig. 2). Therefore we interpret an antiphase behaviour between northern and southern forest communities and an inphase behaviour of fire occurrence in extra-andean steppe and Monte shrublands.

Anthropogenic fires may represent an extra driving factor favouring fire activity between 1000 and 2000 cal yrs BP in southwestern Patagonia due to the more intense

\section{CPD}

$11,2121-2157,2015$

\section{Eastern Andean environmental synthesis for the last 2000 years of Patagonia}

G. D. Sottile et al.

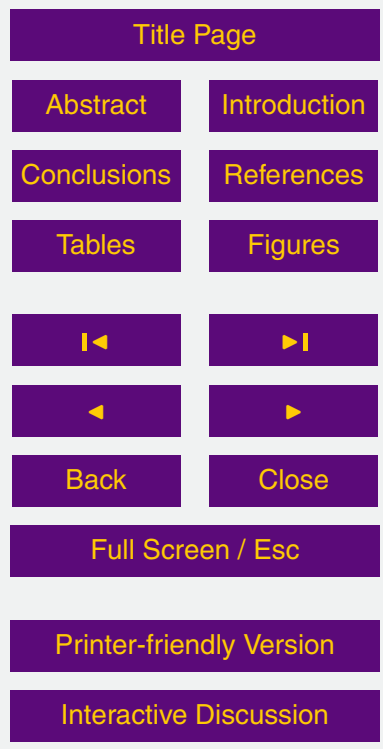


and extensive archaeological signal registered for this area (Franco et al., 2004). However, fire activity registered between 250 and 750 cal years BP is probably related to natural lightning sources since archaeological signal decreases during the last 1000 cal yrs BP in southwestern Patagonia related to an eastward population migration 5 (Franco et al., 2004).

\subsection{Comparison with western Andean precipitation and SWW belt records}

The timing of major SWW changes in latitudinal shift and intensity recorded by the pollen-based Eastern Andean Northern and Southern Patagonia indices performed in this work at 750 calyrs BP (1200 AD) roughly corresponds to a major reorganization of the climate system throughout the world, which is frequently associated to the Little Ice Age originally described in the Northern Hemisphere. Here, we compare our inferredSWW variation during the last 2000 years to western Andean regional precipitation and SWW reconstructions.

Fletcher and Moreno (2012) studied a pollen and charcoal record from Laguna 15 San Pedro ( $38^{\circ} \mathrm{S}$, Fig. 1) located on the western side of the Andes and performed a Nothofagus vs. Poaceae (N/P) index to infer changes in humidity during the last 1500 years. The N/P index shows similar behaviour to our pollen-based Northern Patagonia SWW index (Fig. 4a). Indeed, a brief peak on both indices is registered ca $1100 / 1400$ calyrs BP, suggesting a short period of lower precipitation seasonality 20 under a long term trend of higher precipitation seasonality at both sides of the Andes range. The charcoal record from Laguna San Pedro coincides with eastern Andean Northern Patagonia fire activity during the last 2000 years.

Bertrand et al. (2014) performed a precipitation seasonality index by analysing past two millennia sedimentation changes at Quitralco fjord $\left(46^{\circ} \mathrm{S}\right.$, Fig. 1). The 25 authors suggests a poleward-shifted SWW belt between 1350 and $750 \mathrm{cal}$ yrs BP, followed by a gradual shift towards the equator between 750 and 450 cal yrs BP, and stabilization in a sustained northward position between 450 and 0 calyrs BP (Fig. 4b). The most recent return to a slightly poleward shifted SWW recorded at Quitralco

\section{CPD}

$11,2121-2157,2015$

Eastern Andean environmental synthesis for the last 2000 years of Patagonia

G. D. Sottile et al.

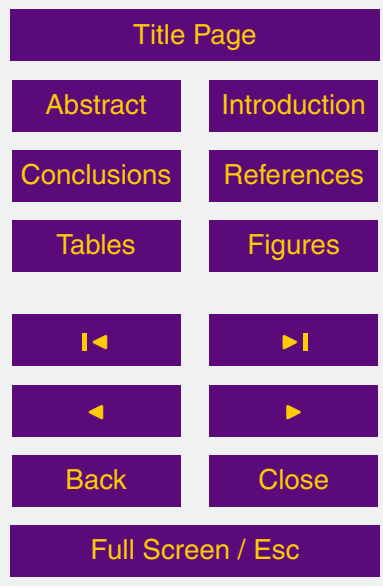

Printer-friendly Version

Interactive Discussion 
fjord, is in agreement with recent trends observed in climatological data (Bertrand et al., 2014). The coincidence between Bertrand's sedimentation based seasonality index and our composite pollen-based Northern Patagonia SWW belt index supports the reliability of our Northern Patagonian proposed past environmental and climate 5 variability scenarios. Similarly, other marine records shows increases on precipitation of SWW origin between 750 and $200 \mathrm{calyrBP}$ at $41^{\circ} \mathrm{S}$ (Lamy et al., 2001) and $44^{\circ} \mathrm{S}$ (Sepulveda et al., 2009).

In Southern Patagonia, Lake Potrok Aike $\left(52^{\circ} \mathrm{S}\right)$ is located where precipitation is negatively correlated with westerly wind strength (Habertzettl et al., 2005). These 10 authors inferred increased lake levels associated to easterly humid flows during weaker westerlies between 490 and 0 calyrs BP. Further south, the MA1 stalagmite record $\left(53^{\circ} \mathrm{S}\right.$, Fig. 1) also provides evidence for a decrease in annual precipitation, and therefore a weakening of the westerlies, since 1000 calyrs BP (Schimpf et al., 2011, Fig. 4d) synchronously with our composite pollen-based Southern Patagonia SWW 15 belt index. Similarly, the sediment record from Lago Fagnano (Waldmann et al., 2010; Fig. 1) suggests a decrease in precipitation of westerly origin, represented by a decrease in iron supply between 750 and 100 cal yrs BP (Fig. 4e). These independent records and Koffman et al. (2013) interpretations of westerlies strength throughout changes in the grain-size of dust particles in the WAIS Divide ice core at Antarctic Peninsula, supports the sensitivity of our Southern Patagonia SWW belt composite pollen-based index to environmental variability.

The slight intensification of the SWW belt ca 300 calyrs BP, coincide with major glaciers advances in southern Patagonia (Aniya, 2013; Masiokas et al., 2009; Mercer et al., 1982; Strelin et al., 2008; Wenzens, 1999) and a Southern Hemisphere extreme cold period inferred by Neukom et al. (2014). Therefore the synergic direction of low temperatures and an increase in hydric balance may have favoured Maunder Minimum glacier advances in Southern Patagonia.

\section{CPD}

$11,2121-2157,2015$

\section{Eastern Andean environmental synthesis for the last 2000 years of Patagonia}

G. D. Sottile et al.

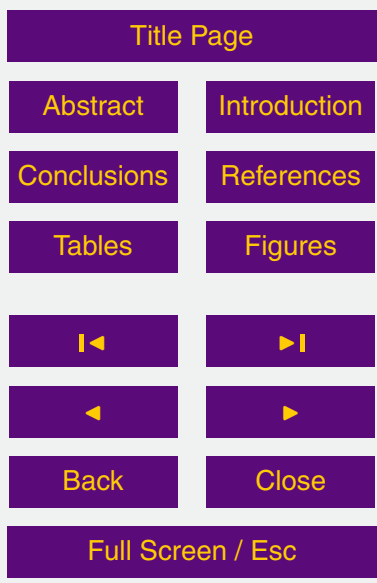

Printer-friendly Version

Interactive Discussion 


\subsection{Changes in SWW belt and possible forcing mechanisms}

Our SWW belt reconstruction suggest southward intensified westerlies since ca 1600 calyrs BP including the MCA (1150-750 calyrs BP) and northward weaker westerlies during LIA (750-150 calyrs BP, Fig. 4c). During LIA, atmospheric cooling 5 in the Southern Hemisphere would have caused a northward shift of the SWW and contraction of the Southern Hemisphere Hadley Cell (Koffman et al., 2013). General circulation model (GCM) experiments have shown that the latitudinal extent of the Hadley cell circulation is sensitive to changes in global surface temperatures, with warmer temperatures causing an expansion of the Hadley cell (Frierson et al., 2007).

10 These changes in the Hadley cell width are likely driven by shifts in the latitude where baroclinic eddies begin to occur; as surface temperatures warm, the transition from baroclinic stability to instability shifts poleward, driving the eddy-driven Southern Hemisphere storm track southward (Frierson et al., 2007; Lu et al., 2010). This proposed mechanism implies that the SWW respond to surface temperature changes 15 on decadal to centennial timescales (Koffman et al., 2013). The mechanism proposed above differs from the seesaw-type redistribution of heat between the hemispheres that was invoked to explain the migration of the SWWB during the last deglaciation (Anderson et al., 2009; Toggweiler, 2009). This suggests that the SWWB may respond to different forcing mechanisms at different timescales (Bertrand et al., 2014). Varma et al. (2011) presented proxy and model evidence that centennial-scale variability in the position of the SWW is significantly influence by fluctuations in solar activity during the past 3000 years. They argued that periods of lower solar activity were associated with annual-mean northward shifts of the SWW, whereas periods of higher solar activity were linked to annual-mean poleward displacements of the SWW.

25 Finally, our results coincide with other inferences predominantly from sea-surface temperature and modelling data about ENSO activity over the last 1500 years, where during the MCA, La Niña like or weak EI Niño conditions and probably positive SAM dominates in Southern South America (Graham et al., 2010; Mann et al., 2009; Rein

\section{CPD}

$11,2121-2157,2015$

\section{Eastern Andean environmental synthesis for the last 2000 years of Patagonia}

G. D. Sottile et al.

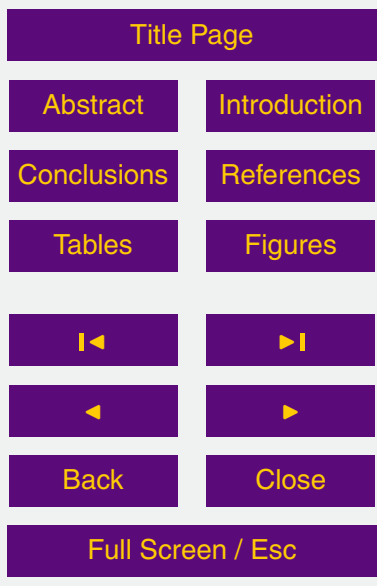

Printer-friendly Version

Interactive Discussion 
et al., 2004; Seager et al., 2007). On the contrary, during LIA dominated more intense EI Niño like conditions and negative SAM values (Mann et al., 2009; Rein et al., 2004; Villalba et al., 2012). The marked decreased in our Northern Patagonia pollen based index suggesting a southward shift of the SWW belt storm track during the last decades 5 coincides with modern climate data measurements (Archer and Caldeira, 2008; Hu and $\mathrm{Fu}, 2007)$ linked to the poleward migration of the descending branch of the Hadley cell (Villalba et al., 2012).

\section{Conclusions}

Pollen and Charcoal records from eastern Andean Patagonia from lake and peatbog 10 records were successfully used to reconstruct late Holocene paleohydric and fire activity variability related to SWW latitudinal and strength variability. Due to the distinct precipitation regimes that exist between Northern $\left(40-45^{\circ} \mathrm{S}\right)$ and Southern Patagonia $\left(48-52^{\circ} \mathrm{S}\right)$ pollen sites locations, shifts on latitudinal and strength of the SWW results in large changes on hydric availability on forest and steppe communities. Therefore, 15 we can interpret fossil available pollen dataset as changes on paleohydric balance at every single site by the construction of paleohydric indices and comparison to charcoal records during the last 2000 cal yrs BP. Our composite pollen-based Northern and Southern Patagonia indices can be interpreted as changes in latitudinal variation and intensity of the SWW respectively. Our eastern Andean pollen and charcoal records synthesis suggest SWW variations during the last 2000 cal yrs BP at centennial scales, with poleward SWW between 1750 and 750 cal yrs BP and northward, weaker SWW between 750 and $200 \mathrm{cal}$ yrs BP. These SWW variations are synchronous to Patagonian fire activity major shifts. We found an in phase fire regime (in terms of timing of biomass burning) between northern Patagonia Monte shrubland and Southern 25 Patagonia steppe environments. Conversely, there is an antiphase fire regime between Northern and Southern Patagonia forest and forest-steppe ecotone environments. For the last 200 calyrs BP we can concluded that the SWW belt were more intense and
CPD

11, 2121-2157, 2015

\section{Eastern Andean environmental synthesis for the last 2000 years of Patagonia}

G. D. Sottile et al.

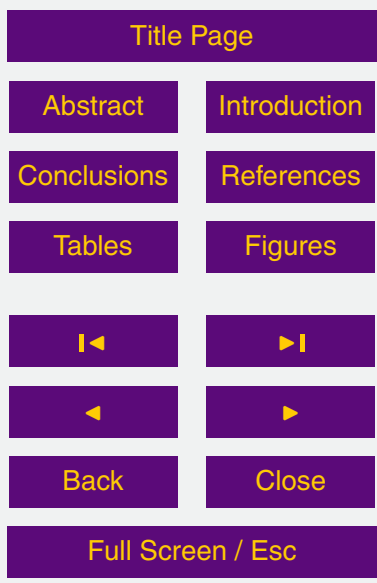

Printer-friendly Version

Interactive Discussion 
poleward than the previous interval, but the last 100 calyrs BP were controversial by the European establishment. Comparison with other precipitation and SWW sensitive Patagonia records from western Andes present coincident late Holocene climatic scenarios. Our composite pollen-based SWW indices shows the potential of integrating 5 pollen dataset at regional scales to improve the understanding of paleohydric variability supported in strongly calibrated pollen-vegetation calibration especially for the last 2000 millennial. However, the scarce availability of continuous pollen or charcoal records on eastern extra-Andean environments still challenge the understanding of past environmental changes on eastern Andean Northern and Southern Patagonia. 10 Our results encourage future palynological research to develop new pollen dataset with high sample resolution and chronological control for the last millennia to calibrate pollen records to other decadal resolution proxy (e.g. dendrocronologycal data, sedimentary or isotopic records). The correspondence of our SWW reconstruction with proposed ENSO variability during LIA and MCA, suggests ENSO-Patagonia centennial scale 15 tele-connection.

\section{The Supplement related to this article is available online at doi:10.5194/cpd-11-2121-2015-supplement.}

Acknowledgements. This research was part of the Ph.D. thesis of Gonzalo D. Sottile at Laboratorio de Paleoecología y Palinología, UNMdP and was supported by PIP-CONICET 1265, UNMDP EXA 642/13, UNMDP EXA 695/14. Data from northern Patagonia and Río Rubens peat bog were obtained from the Neotoma Paleoecology Database (http://www. neotomadb.org), and the work of the data contributors and the Neotoma community is gratefully acknowledged.

\section{CPD}

$11,2121-2157,2015$

Eastern Andean environmental synthesis for the last 2000 years of Patagonia

G. D. Sottile et al.

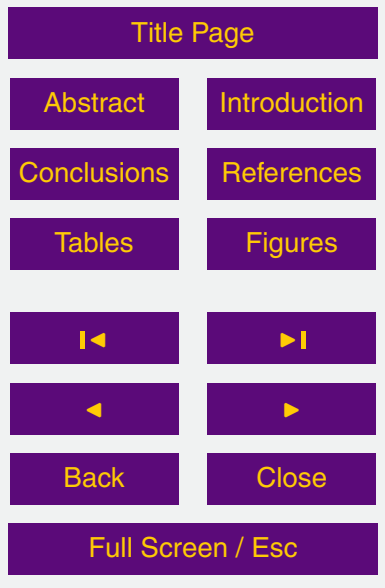

Printer-friendly Version

Interactive Discussion 


\section{References}

Aceituno, P.: On the functioning of the Southern Oscillation in the South American sector, Part 1: Surface climate, Mon. Weather Rev., 116, 505-524, 1988.

Agosta, E., Campagnucci, R., and Ariztegui, D.: Precipitation linked to Atlantic moisture

5 transport: clues to interpret Patagonian palaeoclimate, Clim. Res., 62, 219-240, 2015.

Anderson, R. F., Ali, S., Bradtmiller, L. I., Nielsen, S. H. H., Fleisher, M. Q., Anderson, B. E., and Burckle, L. H.: Wind-driven upwelling in the southern ocean and the deglacial rise in atmospheric $\mathrm{CO}_{2}$, Science, 323, 1443-1448, 2009.

Aniya, M.: Holocene glaciations of Hielo Patagónico (Patagonia Icefield), South America: a brief review, Geochem. J., 47, 97-105, 2013.

Archer, C. L. and Caldeira, K.: Historical trends in the jet streams, Geophys. Res. Lett., 35, L08803, doi:10.1029/2008GL033614, 2008.

Auer, V.: Verschiebungen der Wald- und Steppengebiete Feuerlands in postglazier Zeit, Acta Geogr., 5, 1-313, 1933.

15 Auer, V.: The Pleistocene of Fuegopatagonia, part II: the history of flora and vegetation, Annales Academiae Scientarum Fennicae, 50, 1-239, 1985.

Bamonte, F. P. and Mancini, M. V.: Palaeoenvironmental changes since Pleistocene-Holocene transition: pollen analysis from a wetland in Southwestern Patagonia (Argentina), Rev. Palaeobot. Palyno., 165, 103-110, 2011.

20 Bamonte, F. P., Mancini, M. V., Sottile, G. D., Marcos, M. A., and Gogorza, C.: Vegetation dynamics from Lago San Martín area (Southwest Patagonia, Argentina) during the last 6500 years, Veg. Hist. Archaeobot., 24, 267-277, 2014.

Bertrand, S., Hughen, K., Sepúlveda, J., and Pantoja, S.: Late Holocene covariability of the southern westerlies and sea surface temperature in northern Chilean Patagonia, Quaternary Sci. Rev., 105, 195-208, 2014.

Bianchi, M. M. and Ariztegui, D.: Vegetation history of the Río Manso Superior catchment area, Northern Patagonia (Argentina), since the last deglaciation, Holocene, 22, 1283-1295, 2012.

Bisigato, A. J., Villagra, P. E., Ares, J. O., and Rossi, B. E.: Vegetation heterogeneity in Monte 73, 182-191, 2009.

CPD

$11,2121-2157,2015$

\section{Eastern Andean environmental synthesis for the last 2000 years of Patagonia}

G. D. Sottile et al.

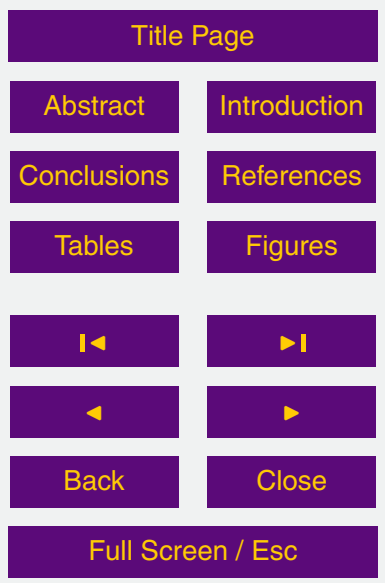

Printer-friendly Version

Interactive Discussion 
Boelcke, O., Moore, D., and Roig, F.: Transecta Botánica de la Patagonia austral, 1st Edn., Consejo Nacional de Investigaciones Científicas y Técnicas, Argentina, Buenos Aires, 1985.

Cabrera, A. L.: Fitogeografía de la República Argentina, BOLETIN de la Sociedad Argentina de Botánica, 14, 1-42, 1971.

5 Cleveland, W. S.: Robust locally weighted fitting and smoothing scatterplots, J. Am. Stat. Assoc., 74, 829-836, 1979.

Cleveland, W. S.: LOWESS: A Program for Smoothing Scatterplots by Robust Locally Weighted Regression, J. Am. Stat. Assoc., 35, p. 54, doi:10.2307/2683591, 1981.

Echeverria, M. E., Sottile, G. D., Mancini, M. V., and Fontana, S. L.: Nothofagus forest dynamics and palaeoenvironmental variations during the mid and late Holocene, in southwest Patagonia, Holocene, 24, 957-969, 2014.

Eddy, J. A.: The Maunder Minimum, Science, 142, 1189-1202, 1976.

Fletcher, M. S. and Moreno, P. I.: Zonally symmetric changes in the strength and position of the Southern Westerlies drove atmospheric $\mathrm{CO}_{2}$ variations over the past $14 \mathrm{ky}$, Geology, 39, 419-422, 2011.

Fletcher, M. and Moreno, P. I.: Vegetation climate and fire regime changes in the Andean region of southern Chile $\left(38^{\circ} \mathrm{S}\right)$ covaried with centennial-scale climate anomalies in the tropical Pacific over the last 1500 years, Quaternary Sci. Rev., 46, 46-56, 2012.

Frierson, D. M. W., Lu, J., and Chen, G.: Width of the Hadley cell in simple and comprehensive general circulation models, Geophys. Res. Lett., 34, L18804, doi:10.1029/2007GL031115, 2007.

Franco, N. V., Borrero, L. A., and Mancini, M. V. Environmental changes and hunter-gatherers in southern Patagonia: Lago Argentino and Cabo Vírgenes (Argentina), Before Farming, 3, 1-17, 2004.

Garreaud, R. D. and Aceituno, P.: Atmospheric circulation over South America: mean features and variability, Chapter 2, in: The Physical Geography of South America, edited by: Veblen, T., Young, K., and Orme, A., Oxford University Press, 2007.

Garreaud, R. D., Vuille, M., Compagnucci, R., and Marengo, J.: Present-day South American Climate, PALAEO 3 Special Issue (LOTRED South America), 281, 180-195, 2009.

30 Garreaud, R., Lopez, P., Minvielle, M., and Rojas, M: Large scale control on the Patagonia climate, J. Climate, 26, 215-230, 2013.

\section{CPD}

11, 2121-2157, 2015

Eastern Andean environmental synthesis for the last 2000 years of Patagonia

G. D. Sottile et al.

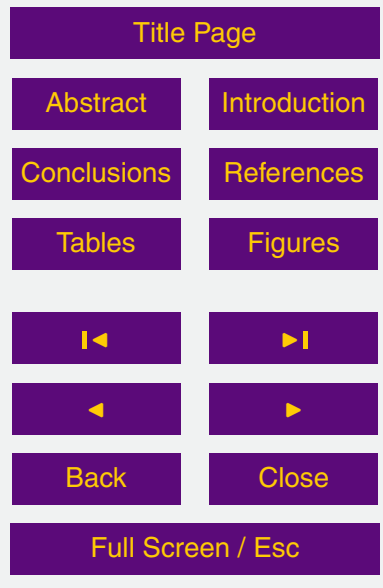

Printer-friendly Version

Interactive Discussion 
Graham, N. E., Ammann, C. M., Fleitmann, D., Cobb, K. M., and Luterbacher, J.: Support for global climate reorganization during the "Medieval Climate Anomaly", Clim. Dynam., 2010, $1-29,2010$.

Haberzettl, T., Fey, M., Lücke, A., Maidana, N., Mayr, C., Ohlendorf, C., Schäbitz, F., Schleser, G., Wille, M., and Zolitschka, B.: Climatically induced lake level changes during the last two millennia as reflected in sediments of Laguna Potrok Aike, southern Patagonia (Santa Cruz, Argentina), J. Paleolimnol., 33, 283-302, 2005.

Hammer, Ø., Harper, D. A. T., and Ryan, P. D.: PAST: Paleontological statistics software package for education and data analysis, Palaeontologí a Electronica, 4, 1-9, 2001.

10 Hardtke, L. A.: Efectos del fuego, modelos de combustible y evaluación de la peligrosidad a diferentes escalas en los ecosistemas del Monte Patagónico, Thesis, National University of Comahue, Argentina, 2014.

Heusser, C. J. and Heusser, L. E.: Submillennial palynology and palaeoecology of the last glaciation at Taiquemó (50.000 cal yr, MIS 2-4) in Southern Chile, Quaternary Sci. Rev., 25, 446-454, 2006.

Higuera, P. E., Brubaker, L. B., Anderson, P. M., Hu, F. S., and Brown, T. A.: Vegetation mediated the impacts of postglacial climatic change on fire regimes in the south-central Brooks Range, Alaska, Ecol. Monogr., 79, 201-219, 2009

Hijmans, R. J., Cameron, S. E., Parra, J. L., Jones, P. G., and Jarvis, A.: Very high resolution interpolated climate surfaces for global land areas, Int. J. Climatol., 25, 1965-1978, 2005.

Hogg, A. G.,Hua, Q., Blackwell, P. G., Niu, M., Buck, C. E., Guilderson, T. P., Heaton, T. J., Palmer, J. G., Reimer, P. J., Reimer, R. W., Turney, C. S. M., and Zimmerman, S. R. H.: SHCal13 Southern Hemisphere calibration, 0-50,000 years cal BP, Radiocarbon, 55, 8891903, 2013.

Holz, A. and Veblen, T. T.: Variability in the Southern Annular Mode determines wildfire activity in Patagonia, Geophys. Res. Lett., 38, L14710, doi:10.1029/2011GL047674, 2011.

$\mathrm{Hu}, \mathrm{Y}$. and Fu, Q.: Observed poleward expansion of the Hadley circulation since 1979, Atmos. Chem. Phys., 7, 5229-5236, doi:10.5194/acp-7-5229-2007, 2007.

Huber, U. M. and Markgraf, V.: European impact on fire regimes and vegetation dynamics at the steppe-forest ecotone of southern Patagonia, Holocene, 13, 567-579, 2003a.

Huber, U. M. and Markgraf, V.: Holocene fire frequency and climate change at Rio Rubens Bog, southern Patagonia, in: Fire and Climatic Change in Temperate Ecosystems of the Western
CPD

11, 2121-2157, 2015

\section{Eastern Andean environmental synthesis for the last 2000 years of Patagonia}

G. D. Sottile et al.

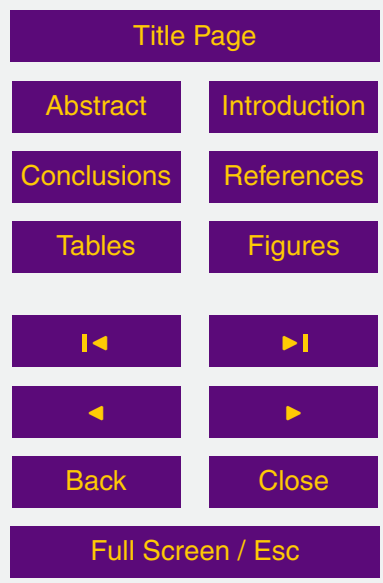

Printer-friendly Version

Interactive Discussion 
Americas, edited by: Veblen, T. T., Baker, W. L., Montenegro, G., and Swetnam, T. W., Springer Verlag, New York, 357-380, 2003b.

Huber, U. M., Markgraf, V., and Schäbitz, F.: Geographical and temporal trends in late quaternary fire histories of Fuego-Patagonia South America, Quaternary Sci. Rev., 23, 191198, 2004.

Iglesias, V.: Holocene climate-vegetation-fire linkages along the Patagonian forest/steppe ecotone $\left(41-43^{\circ} \mathrm{S}\right)$, Doctoral dissertation, Montana State University, Bozeman, Montana, USA, 2013.

Iglesias, V. and Whitlock, C.: Fire responses to postglacial climate change and human impact in northern Patagonia $\left(41-43^{\circ}\right.$ S), P. Natl. Acad. Sci. USA, 111, E5545-E5554, doi:10.1073/pnas.1410443111, 2014.

Iglesias, V., Whitlock, C., Bianchi, M. M., Villarosa, G., and Outes, V.: Climate and local controls of long-term vegetation dynamics in northern Patagonia (Lat $41^{\circ} \mathrm{S}$ ), Quaternary Res., 78, 502-512, 2012a.

15 Iglesias, V., Whitlock, C., Bianchi, M. M., Villarosa, G., and Outes, V.: Holocene climatic variability and environmental history at the Patagonian forest/steppe ecotone: Lago Mosquito and Laguna del Cóndor, Holocene, 22, 1297-1307, 2012b.

Iglesias, V., Whitlock, C., Markgraf, V., and Bianchi. M. M.: Postglacial history of the Patagonian forest/steppe ecotone (41-43 ${ }^{\circ}$ S), Quaternary Sci. Rev., 94, 120-135, 2014.

20

Jacobson Jr., G. L. and Bradshaw, R. H. W.: The selection of sites for paleovegetational studies, Quaternary Res., 16, 80-96, 1981.

Jones, P. D. and Mann, M. E.: Climate over past millennia, Rev. Geophys., 42, 1-42, 2004.

Jones, P. D., Osborn, T. J., and Briffa, K. R.: The evolution of climate over the last millennium, Science, 292, 662-667, 2001.

Killian, R. and Lamy, F.: A review of Glacial and Holocene paleoclimate records from southernmost Patagonia (49-55 ${ }^{\circ}$ S), Quaternary Sci. Rev., 53, 1-23, 2012.

Kitzberger, T.: Ecotones as Complex Arenas of Disturbance, Climate and Human Impacts: The Trans-Andean Forest-Steppe Ecotone of Northern Patagonia, Ecotones Between Forest and Grassland, edited by: Myster, R., Springer, New York, 59-88, 2012.

30 Kitzberger, T., Raffaele, E., Heinemann, K., and Mazzarino, M. J.: Effects of fire severity in a north Patagonian subalpine forest, J. Veg. Sci., 16, 5-12, 2005.

Koffman, B. G., Kreutz, K. J., Breton, D. J., Kane, E. J., Winski, D. A., Birkel, S. D., Kurbatov, A. V., and Handley, M. J.: Centennial-scale variability of the Southern Hemisphere westerly
CPD

11, 2121-2157, 2015

\section{Eastern Andean environmental synthesis for the last 2000 years of Patagonia}

G. D. Sottile et al.

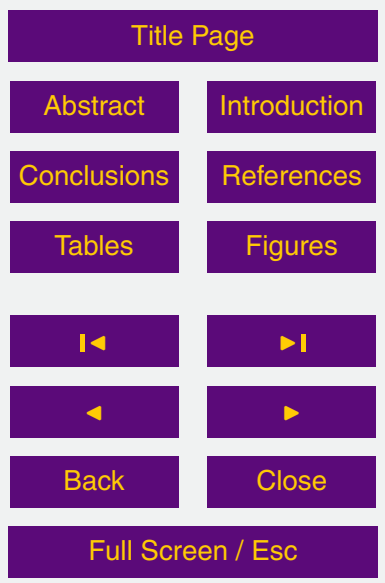

Printer-friendly Version

Interactive Discussion 
wind belt in the eastern Pacific over the past two millennia, Clim. Past, 10, 1125-1144, doi:10.5194/cp-10-1125-2014, 2014.

Lamy, F., Hebbeln, D., Rohl, U., and Wefer, G.: Holocene rainfall variability in southern Chile: a marine record of latitudinal shifts of the Southern Westerlies, Earth Planet. Sc. Lett., 185, $5 \quad 369-382,2001$.

Lamy, F., Kilian, R., Arz, H. W., Francois, J.-P., Kaiser, J., Prange, M., and Steinke, T.: Holocene changes in the position and intensity of the southern westerly wind belt, Nat. Geosci., 3, 695-699, 2010.

León, R. J. C., Bran, D., Collantes, M., Paruelo, J. M., and Soriano, A.: Grandes unidades de 10 vegetación de la Patagonia extra andina, Ecología Austral., 8, 125-144, 1998.

Lu, J., Chen, G., and Frierson, D. M.: The Position of Midlatitude Storm Track and Eddy-Driven Westerlies in Aquaplanet AGCMs, J. Atmos. Sci., 67, 3984-4000, 2010.

Mancini, M. V.: Variabilidad climática durante los últimos 1000 años en el área de Cabo Vírgenes, Argentina, Ameghiniana, 44, 173-182, 2007.

15 Mancini, M. V.: Holocene vegetation and climate changes from a peat pollen record of the forest-steppe ecotone, southwest of Patagonia (Argentina), Quaternary Sci. Rev., 28, 14901497, 2009.

Mancini, M. V. and Graham, M.: Registros polínicos de depósitos del Holoceno en el Sudeste de Patagonia, Argentina: su aplicación en la reconstrucción paleoambiental, Ameghiniana, $20 \quad$ 51, 194-208, 2014.

Mancini, M. V., Prieto, A. R., Paez, M. M., and Schabitz, F.: Late quaternary vegetation and climate of Patagonia, in: Late Cenozoic of Patagonia and Tierra del Fuego, Vol. 11, cap. 17, edited by: Rabassa, J., Developments in Quaternary Sciencies, Elsevier, Amsterdam, The Netherlands, 351-367, 2008.

Mancini, M. V., de Porras, M. E., and Bamonte, F. P.: Southernmost South America steppes: vegetation and its modern pollenassemblages representation, in: Steppe Ecosystems: Dynamics, Land Use and Conservation, edited by: Germanno, D., NOVA publishers, New York, 141-156, 2012.

Mann, M. E., Zhang, Z., Rutherford, S., Bradley, R. S., Hughes, M. K., Shindell, D., Ammann, C., 30 Faluvegi, G., and Ni, F.: Global signatures and dynamical origins of the Little Ice Age and Medieval Climate Anomaly, Science, 326, 1256-1260, 2009.

Marcos, M. A. and Mancini, M. V.: Modern pollen and vegetation relationships in northeastern Patagonia (Golfo San Matías, Río Negro), Rev. Palaeobot. Palyno., 171, 19-26, 2012.

\section{CPD}

11, 2121-2157, 2015

\section{Eastern Andean environmental synthesis for the last 2000 years of Patagonia}

G. D. Sottile et al.

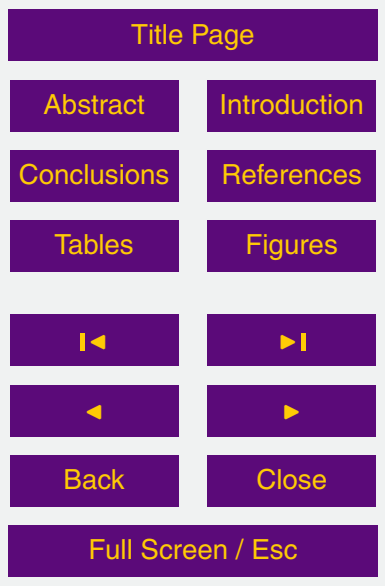

Printer-friendly Version

Interactive Discussion 
Marcos, M. A. and Ortega, F. V.: Paleoambientes y uso de los recursos leñosos por los grupos cazadores-recolectores del NE de Patagonia desde el Holoceno medio, Magallania, 42, 147163, 2014.

Marcos, M. A., Mancini, M. V., and Favier Dubois, C. M.: Middle to late Holocene environmental 5 changes in Bajo de la Quinta, NE Patagonia, inferred by palynological records and their relation to human occupation, Holocene, 22, 1271-1281, 2012a.

Marcos, M. A., Sottile, G. D., Gogorza, C., and Irurzun, M. A.: Reconstrucción de la vegetación y de los regímenes de fuego durante el Holoceno tardío en el noreste de Patagonia, XV Simposio Argentino de paleobotánica y Palinología, 10-13 de julio, Corrientes, Argentina, 2012b.

Marcos, M. A., Espinosa, M. A., Mancini, M. V., and Favier Dubois, C. M.: Múltiples indicadores de los cambios ambientales desde el Holoceno Medio en el Noreste de Patagonia (Bajo de la Quinta), Argentina, Ameghiniana, 51, 344-360, 2014.

Markgraf, V. and Anderson, L.: Fire history of Patagonia: climate versus human cause, Revista 15 do instituto Geológico, Rev. Inst. Geol., 15, 35-47, 1994.

Markgraf, V. and Huber, U. M.: Late and postglacial vegetation and fire history in southern Patagonia and Tierra del Fuego, Palaeogeogr. Palaeocl., 297, 351-366, 2010.

Markgraf, V., Bradbury, J. P., and Schwalb, A.: Holocene paleoclimates of southern Patagonia: limnological and environmental history of Lago Cardiel, Argentina, Holocene, 13, 581-591, 2003.

Markgraf, V., Whitlock, C., and Haberle, S. G.: Vegetation and fire history during the last $18000 \mathrm{cal}$ yr B. P. in southern Patagonia: Mallin Pollux, Coyhaique, Province Aisén $\left(45^{\circ} 41^{\prime} 30^{\prime \prime} \mathrm{S}, 71^{\circ} 50^{\prime} 30^{\prime \prime} \mathrm{W}\right), 640$ m elevation, Palaeogeogr. Palaeocl., 254, 492-507, 2007.

Masiokas, M. H., Luckman, B. H., Villalba, R., Delgado, S., Skvarca, P., and Ripalta, A.: Little 25 Ise Age fluctuations of small glaciers in the Monte Fitz Roy and Lago del Desierto areas, south Patagonian Andes, Argentina, Palaeogeogr. Palaeocl., 281, 351-362, 2009.

Mercer, J. H.: Holocene glacier variations in southern South America, Striae, 18, 35-40, 1982.

Mermoz, M., Kitzberger, T., and Veblen, T. T.: Landscape influences on occurrence and spread of wildfires in Patagonian forests and shrublands, Ecology, 86, 2705-2715, 2005.

30 Meyer, I. and Wagner, S: The Little Ice Age in southern Patagonia: comparison between paleoecological reconstructions and downscaled model ouput of a GCM simulation, Pages News, 16, 12-13, 2008.

\section{CPD}

$11,2121-2157,2015$

\section{Eastern Andean environmental synthesis for the last 2000 years of Patagonia}

G. D. Sottile et al.

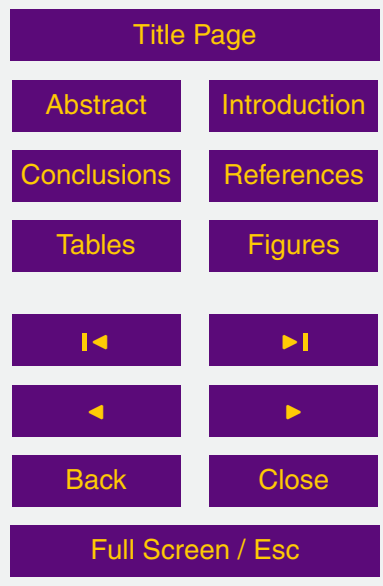

Printer-friendly Version

Interactive Discussion 
Montecinos, A., Díaz A., and Aceituno, P.: Seasonal diagnostic and predictability of rainfall in subtropical South America based on tropical Pacific SST, J. Climate, 13, 746-758, 2000.

Moreno, P. I., Francois, J. P., Villa-Martinez, R. P., and Moy, C. M.: Millennial-scale variability in Southern Hemisphere westerly wind activity over the last 5000 years in SW Patagonia,

5 Quaternary Sci. Rev., 28, 25-38, 2009.

Moreno, P. I., Kitzberger, T., Iglesias, V., and Holz, A.: Paleofires in southern South America since the Last Glacial Maximum, Pages News, 18, 75-77, 2010.

Moreno, P. I., Vilanova, I., Villa-Martínez R., Garreaud, R. D., Rojas, M., and De Pol-Holz, R.: Southern annular mode-like changes in southwestern Patagonia at centennial timescales over the last three millennia, Nature Communications, 5, 4375, doi:10.1038/ncomms5375, 2014.

Morgan, P., Defoseé, G. E., and Rodriguez, N. F.: Management implications of fire and climate in Western Americas, in: Fire and Climatic Changes in Temperate Ecosystems of the Western Americas, edited by: Veblen, T. T., Baker, W., Montenegro, G., and Swetnam, T. W., 15 Springer, New York, 413-440, 2003.

Moy, C. M., Dunbar, R. B., Moreno, P., Francois, J. P., Villa-Martinez, R., Guilderson, T. P., and Garreaud, R. D.: Isotopic evidence for hydrologic change related to the westerlies in SW Patagonia, Chile, during the last millennium, Quaternary Sci. Rev., 27, 1335-1349, 2009.

Mundo, I. A., Wiegand, T., Kanagaraj, R., and Kitzberger, T.: Environmental drivers and spatial 20 dependency in wildfire ignition patterns of northwestern Patagonia, J. Environ. Manage., 123, 77-87, 2013.

Neukom, R., Luterbacher, J., Villalba, R., Küttel, M., Frank, D., Jones, P. D., Grosjean, M., Esper, J., Lopez, L., and Wanner, H.: Multi-centennial summer and winter precipitation variability in southern South America, Geophys. Res. Lett., 37, L14708, doi:10.1029/2010GL043680, 2010.

Neukom, R., Luterbacher, J., Villalba, R., Küttel, M., Frank, D., Jones, P. D., Grosjean, M., Wanner, H., Aravena, J. C., Black, D. E., Christie, D. A., D’Arrigo, R., Larra, A., Morales, M., Soliz-Gamboa, C., Srur, A., Urrutia, R., and von Gunten, L.: Multiproxy summer and winter surface air temperature field reconstructions for southern South America covering the past centuries, Clim. Dynam., 37, 35-51, 2011.

Neukom, R., Gergis, J., Karoly, D. J., Wanner, H., Curran, M., Elbert, J., Gonzalez-Rouco, F., Linsley, B. K., Moy, A. D., Mundo, I., Raible, C. C., Steig, E. J., van Ommen, T., Vance, T.,

CPD

11, 2121-2157, 2015

\section{Eastern Andean environmental synthesis for the last 2000 years of Patagonia}

G. D. Sottile et al.

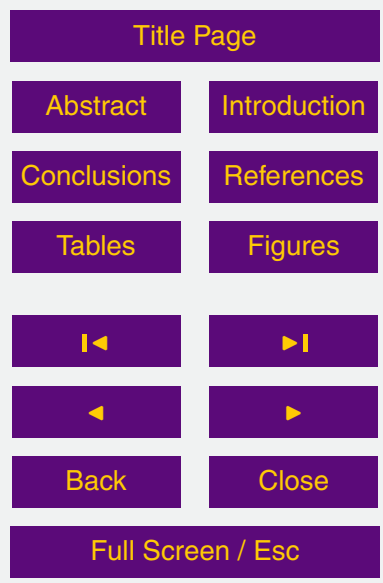

Printer-friendly Version

Interactive Discussion 
Villalba, R., Zinke, J., and Frank, D.: Inter-hemispheric temperature variability over the past millennium, Nature Climate Change, 4, 362-367, 2014.

Osborn, T. J. and Briffa, K. R.: The spatial extent of 20th-century warmth in the context of the past 1200 years, Science, 311, 841-844, 2006.

5 Paez, M. M., Schäbitz, F., and Stutz, S.: Modern pollen-vegetation and isopoll maps in southern Argentina, J. Biogeogr., 28, 997-1021, 2001.

Paruelo, J. M., Beltrán, A., Jobbágy, E., Sala, O. E., and Golluscio, R. A.: The climate of Patagonia: general patterns and controls on biotic processes, Ecología Austral., 8, 85-101, 1998.

10 Prohaska, F.: The climate of Argentina, Paraguay and Uruguay, in: Climates of Central and South America, edited by: Schwerdtfeger, W., Elsevier, Amsterdam, 13-112, 1976.

Rein, B., Lückge, A., and Sirocko, F.: A major Holocene ENSO anomaly during the Medieval period, Geophys. Res. Lett., 31, L17211, doi:10.1029/2004GL020161, 2004.

Rutllant, J. and Fuenzalida, H.: Synoptic aspects of the central chile rainfall variability associated with the southern oscillation, Int. J. Climatol., 11, 63-76, 1991.

Schimpf, D., Kilian, R., Kronz, A., Simon, K., Spötl, C., Wörner, G., Deininger, M., and Mangini, A.: The significance of chemical, isotopic, and detrital components in three coeval stalagmites from the superhumid southernmost Andes $\left(53^{\circ} \mathrm{S}\right)$ as high-resolution palaeoclimate proxies, Quaternary Sci. Rev., 30, 443-459, 2011.

20 Seager, R., Graham, N., Herweijer, C., Gordon, A. L., Kushnir, Y., and Cook, E.: Blueprints for Medieval hydroclimate, Quaternary Sci. Rev., 26, 2322-2336, 2007.

Sepúlveda, J., Pantoja, S., Hughen, K. A., Bertrand, S., Figueroa, D., León, T., Drenzek, N. J., and Lange, C.: Late Holocene sea-surface temperature and precipitation variability in northern Patagonia, Chile (Jacaf Fjord, 44 S), Quaternary Res., 72, 400-409, 2009.

Sottile, G.: Historia de la vegetación vinculada a disturbios de incendios durante el Holoceno en el ecotono bosque-estepa de Santa Cruz, Argentina, PhD thesis, National University of Mar del Plata, Argentina, 2014.

Sottile, G., Bamonte, F. P., Mancini, M. V., and Bianchi, M. M.: Insights into Holocene vegetation and climate changes at the southeast of the Andes: Nothofagus forest and Patagonian steppe fire records, Holocene, 22, 1201-1214, 2012.

Strelin, J., Casassa, G., Rosqvist, G., and Holmlund, P.: Holocene glaciations in the Ema Glacier valley, Monte Sarmiento Massif, Tierra del Fuego, Palaeogeogr. Palaeocl., 260, 299314, 2008.

\section{CPD}

$11,2121-2157,2015$

\section{Eastern Andean environmental synthesis for the last 2000 years of Patagonia}

G. D. Sottile et al.

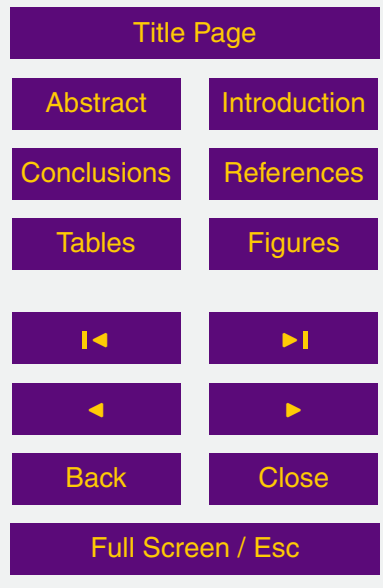

Printer-friendly Version

Interactive Discussion 
Stuiver, M., Reimer, P. J., and Reimer, R. W.: Rev 7.1 CALIB program, available at: http://calib. qub.ac.uk/calib/, last access: 1 March 2015, 2005.

Thornthwaite, C. W.: An approach toward a rational classification of climate, Geogr. Rev., 38, 55-94, 1948.

5 Toggweiler, J. R.: Shifting westerlies, Science 323, 1434-1435, 2009.

Toggweiler, J. R., Russel, J. L., and Carson, S. R.: Midlatitude westerlies, atmospheric $\mathrm{CO}_{2}$ and climate change during the ice ages, Paleoceanography, 21, PA2005, doi:10.1029/2005PA001154, 2006.

Tonello, M., Mancini, M. V., and Seppä, H.: Quantitative reconstruction of Holocene precipitation changes in southern Patagonia, Quaternary Res., 72, 410-420, 2009.

Varma, V., Prange, M., Lamy, F., Merkel, U., and Schulz, M.: Solar-forced shifts of the Southern Hemisphere Westerlies during the Holocene, Clim. Past, 7, 339-347, doi:10.5194/cp-7-3392011, 2011.

Varma, V., Prange, M., Merkel, U., Kleinen, T., Lohmann, G., Pfeiffer, M., Renssen, H., 15 Wagner, A., Wagner, S., and Schulz, M.: Holocene evolution of the Southern Hemisphere westerly winds in transient simulations with global climate models, Clim. Past, 8, 391-402, doi:10.5194/cp-8-391-2012, 2012.

Veblen, T. T., Kitzberger, T., Burns, B. R., and Rebertus, A. J.: Perturbaciones y dinámica de regeneración en bosques andinos del sur de Chile y Argentina, in: Ecología de los bosques nativos de Chile, edited by: Arnesto, J. J., Villagrán, C., and Arroyo, M. R., Editorial Universitaria, Santiago de Chile, Chile, 169-198, 1997.

Veblen, T. T., Kitzberger, T., Villalba, R., and Donnegan, J.: Fire history in northern Patagonia: the roles of humans and climatic variation, Ecol. Monogr., 69, 47-67, 1999.

Villalba, R., Grosjean, M., and Kieker, T.: Long-term multi-proxy climate reconstructions and 25 dynamics in South America (LOTRED-SA): state of the art and perspectives, Palaeogeogr. Palaeocl., 281, 175-179, 2009.

Villalba, R., Lara, A., Masiokas, M. H., Urrutia, R., Luckman, B. H., Marshall, G. J., and Mundo, I. A.: Unusual Southern Hemisphere tree groth patterns induced by changes in the Southern Annular Mode, Nat. Geosci, 5, 793-798, doi:10.1038/NGEO1613, 2012.

so Waldmann, N., Ariztegui, D., Anselmetti, F. S., Austin, J. A., Moy, C. M., Stern, C., Recasens, C., Dunbar, R. B.: Holocene climatic fluctuations and positioning of the Southern Hemisphere westerlies in Tierra del Fuego (54 S), Patagonia. J. Quat. Sci. 25, 1063-1075, 2010.

CPD

11, 2121-2157, 2015

\section{Eastern Andean environmental synthesis for the last 2000 years of Patagonia}

G. D. Sottile et al.

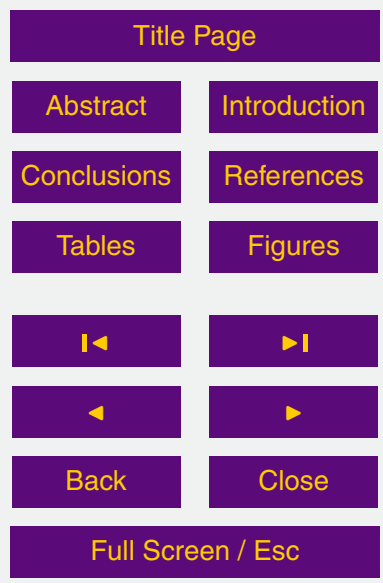

Printer-friendly Version

Interactive Discussion 
Wenzens, G.: Fluctuations of outlet and valley glaciers in the Southern Andes (Argentina) during the past 13,000 years, Quaternary Res., 51, 238-247, 1999.

Whitlock, C., Bianchi, M. M., Bartlein, P. J., Markgraf, V., Marlon, J., Walsh, M., and McCoy, N.: Postglacial vegetation, climate, and fire history along the east side of the Andes (lat 4142.5 S), Argentina, Quaternary Res., 66, 187-201, 2006.

Whitlock, C., Moreno, P., and Bartlein, P. J.: Climatic controls of Holocene fire patterns in southern South America, Quaternary Res., 68, 28-36, 2007.

Wille, M., Maidana, N., Schäbitz, F., Fey, M., Haberzettl, T., and Janssen S: Vegetation and climate dynamics in southern south America: the micro-fossil record of Laguna Potrok Aike, Santa Cruz, Argentina, Rev. Palaeobot. Palyno., 146, 234-246, 2007.

Wilmes, S. B., Raible, C. C., and Stocker, T. F.: Climate variability of the mid- and high-latitudes of the Southern Hemisphere in ensemble simulations from 1500 to 2000 AD, Clim. Past, 8, 373-390, doi:10.5194/cp-8-373-2012, 2012.

Zorita, E., von Storch, H., González-Rouco, F., Cubasch, U., Luterbacher, J., Legutke, S., 15 Fischer-Bruns, I., and Schlese, U.: Climate evolution in the last five centuries simulated by an atmosphere-ocean model: global tempertures, the North Atlantic Oscillation and the Late Maunder Minimum, Meteorol. Z., 13, 271-289, 2004.

CPD

$11,2121-2157,2015$

\section{Eastern Andean environmental synthesis for the last 2000 years of Patagonia}

G. D. Sottile et al.

\section{Title Page}

Abstract

Introduction

Conclusions

References

Tables

Figures

14

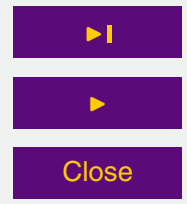

Back

Close

Full Screen / Esc

Printer-friendly Version

Interactive Discussion 
Table 1. Sites selected for Eastern Andean environmental synthesis. Asterisks points improved chronological control of dataset for this work (see Supplement, Sect. 2). Precipitation and temperature values to calculate Hydric balance index was imported from WorldClim database (http://www.worldclim.org: Hijmans et al., 2005) into GIS software (QGis 2.6.1). Data were first interpolated by krigging method and then monthly values were extracted and the mean values were calculated for sampled sites. Hydric balance index was calculated for each site as the ratio between annual precipitation and potential evapotranspiration. Potential evapotranspiration values were estimated according to Thornthwaite (1948).

\begin{tabular}{|c|c|c|c|c|c|}
\hline $\begin{array}{l}\text { Site } \\
\text { (coordinates) }\end{array}$ & $\begin{array}{l}\text { Modern } \\
\text { hydric } \\
\text { balance } \\
\left(\mathrm{mmyr}^{-1}\right)\end{array}$ & Vegetation & $\begin{array}{c}\text { Data set } \\
\text { resolution } \\
\left(\text { sampleyrs }^{-1}\right)\end{array}$ & $\begin{array}{l}\text { Number of datings } \\
\text { (radiocarbon or } \\
\text { Pb2010) during } \\
\text { the last } 2300 \text { years }\end{array}$ & References \\
\hline $\begin{array}{l}\text { Lake Trébol } \\
-41.15^{\circ} \mathrm{S} \\
-71.32^{\circ} \mathrm{W}\end{array}$ & 4993.7 & $\begin{array}{l}\text { N. dombeyi and } \\
\text { Austrocedrus chilensis } \\
\text { forest }\end{array}$ & 136 & 3 & $\begin{array}{l}\text { Whitlock et al. (2006), Iglesias (2013), } \\
\text { Iglesias and Whitlock (2014), } \\
\text { Iglesias et al. (2014) }\end{array}$ \\
\hline $\begin{array}{l}\text { Lake Theobald } \\
-43.48^{\circ} \mathrm{S} \\
-71.58^{\circ} \mathrm{W}\end{array}$ & 8.60 & $\begin{array}{l}\text { N. dombeyi and } \\
\text { Austrocedrus chilensis/ } \\
\text { steppe }\end{array}$ & 156 & 2 & $\begin{array}{l}\text { Iglesias and Whitlock (2014), } \\
\text { Iglesias et al. (2014) }\end{array}$ \\
\hline $\begin{array}{l}\text { Lake Mosquito } \\
-42.49^{\circ} \mathrm{S} \\
-71.39^{\circ} \mathrm{W}\end{array}$ & 143.2 & $\begin{array}{l}\text { Austrocedrus chilensis } \\
\text { stands/steppe }\end{array}$ & 53 & 5 & $\begin{array}{l}\text { Whitlock et al. (2006), } \\
\text { Iglesias et al. (2012, 2014), } \\
\text { Iglesias (2013), Iglesias and Whitlock (2014) }\end{array}$ \\
\hline $\begin{array}{l}\text { Mallín Pollux } \\
-45.69^{\circ} \mathrm{S} \\
-71.84^{\circ} \mathrm{W}\end{array}$ & 264.4 & $\begin{array}{l}\text { N. pumilio and } \\
\text { N. antarctica } \\
\text { forest/steppe }\end{array}$ & 114 & 3 & Markgraf et al. (2007) \\
\hline $\begin{array}{l}\text { Bajo de la Quinta (BQ) } \\
-40.92^{\circ} \mathrm{S} \\
-64.33^{\circ} \mathrm{W}\end{array}$ & -516.3 & Monte shrubland & 136 & $3^{*}$ & Marcos et al. $(2012 a, b, 2014)$ \\
\hline $\begin{array}{l}\text { PAA peat-bog } \\
-50.26^{\circ} \mathrm{S} \\
-72.85^{\circ} \mathrm{W}\end{array}$ & 104.5 & N. pumilio forest & 61 & 3 & $\begin{array}{l}\text { Sottile (2014), } \\
\text { this work, } \\
\text { Supplement (Sect. S1) }\end{array}$ \\
\hline $\begin{array}{l}\text { PAB peat-bog } \\
-50.26^{\circ} \mathrm{S} \\
-72.84^{\circ} \mathrm{W}\end{array}$ & 67.2 & $\begin{array}{l}N . \text { pumilio forest } \\
\text { and } N \text {. antarctica } \\
\text { steppe }\end{array}$ & 85 & 3 & Echeverría et al. (2014) \\
\hline $\begin{array}{l}\text { Cerro Frías peat-bog (CF) } \\
-50.41^{\circ} \mathrm{S} \\
-72.71^{\circ} \mathrm{W}\end{array}$ & -65 & $\begin{array}{l}\text { Forest/steppe } \\
\text { ecotone }\end{array}$ & 92 & 2 & $\begin{array}{l}\text { Mancini (2009), } \\
\text { Sottile et al. (2014) }\end{array}$ \\
\hline $\begin{array}{l}\text { Río Rubens peat-bog (RR) } \\
-52.06^{\circ} \mathrm{S} \\
-71.51^{\circ} \mathrm{W}\end{array}$ & -189.8 & $\begin{array}{l}\text { Forest } \\
\text { steppe/ecotone }\end{array}$ & 60 & 9 & $\begin{array}{l}\text { Huber and Markgraf (2003a, b), } \\
\text { Huber et al. (2004), } \\
\text { Markgraf andHuber (2010) }\end{array}$ \\
\hline $\begin{array}{l}\text { Mallín Paisano Desconocido (MPD) } \\
-48.95^{\circ} \mathrm{S} \\
-72.23^{\circ} \mathrm{W}\end{array}$ & -163.2 & Grass steppe & 159 & 2 & Bamonte et al. (2014) \\
\hline $\begin{array}{l}\text { La Tercera peat-bog (LT) } \\
-49.182^{\circ} \mathrm{S} \\
-72.37^{\circ} \mathrm{W}\end{array}$ & -146.6 & Grass steppe & 171 & $2^{*}$ & $\begin{array}{l}\text { Bamonte and Mancini (2011), } \\
\text { Sottile et al. (2012) }\end{array}$ \\
\hline $\begin{array}{l}\text { Mallín Cabo Vírgenes (CV) } \\
-52.32^{\circ} \mathrm{S} \\
-68.38^{\circ} \mathrm{W}\end{array}$ & -303.7 & Grass steppe & 61 & $\begin{array}{l}2 \text { (in the last } \\
1100 \text { years) }\end{array}$ & $\begin{array}{l}\text { Mancini (2007), } \\
\text { Mancini and Graham (2014) }\end{array}$ \\
\hline
\end{tabular}

\section{CPD}

$11,2121-2157,2015$

\section{Eastern Andean environmental synthesis for the last 2000 years of Patagonia}

G. D. Sottile et al.

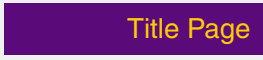

Abstract

Introduction

Conclusions

References

Tables

Figures

14

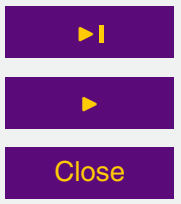

Back

Close

\section{Full Screen / Esc}

Printer-friendly Version

Interactive Discussion 
a.

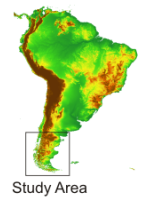

$\square$ Monte shrubland $\square$ Dwarf-Shrub stappe Shrub steppe $\square$ Grass steppe Nothofagus - Austrocoedrus forest Nothofagus spp. forest
Vegetation units

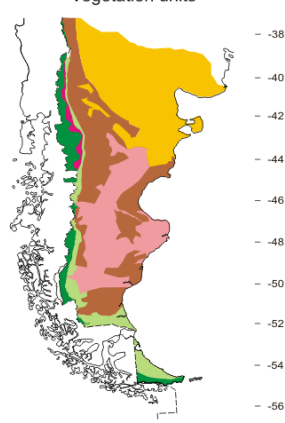

b.

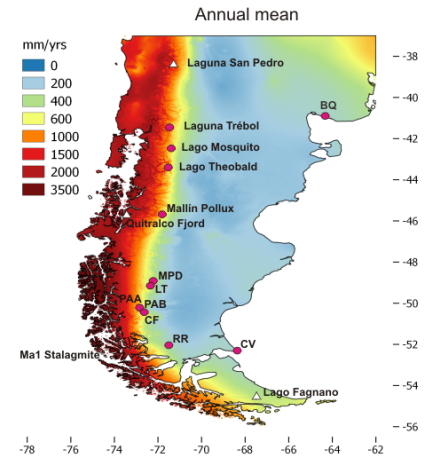

Eastern Andean sites included in this synthesis

$\triangle$ Western Andean SWW belts sensitive proxy records previously published
C.

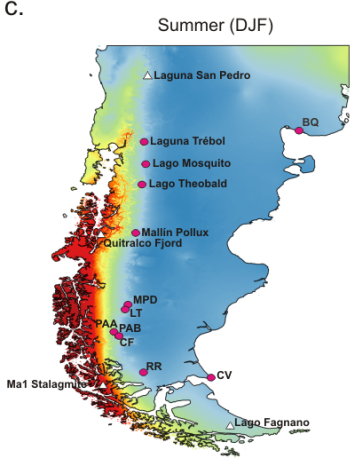

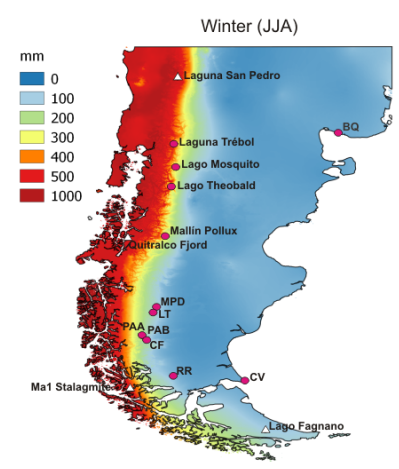

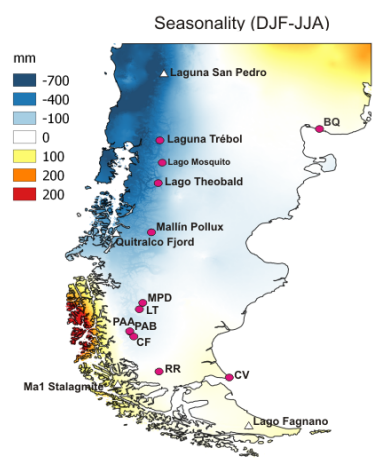

Figure 1. Modern hydroclimatology (1950-2000) of Patagonia. (a) Main vegetation units of eastern Andean Patagonia modified from Cabrera (1971), León et al. (1998) and Mancini et al. (2012). (b) Annual mean precipitation. (c) The seasonality index was calculated as the ratio between summer precipitation and winter (DJF/JJA). Values lower (higher) than 1 are therefore indicative of regions where precipitation is higher (lower) in winter than in summer. Austral winter (JJA) and summer (DJF) precipitation and difference between the two (seasonality). The precipitation maps were created using data from the Worldclim database (Hijmans et al., 2005).

CPD

$11,2121-2157,2015$

\section{Eastern Andean environmental synthesis for the last 2000 years of Patagonia}

G. D. Sottile et al.

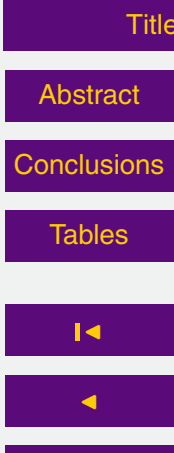

Title Page

Back

Introduction

References

Figures

$>1$

$>$

Close

\section{Full Screen / Esc}

Printer-friendly Version

Interactive Discussion 


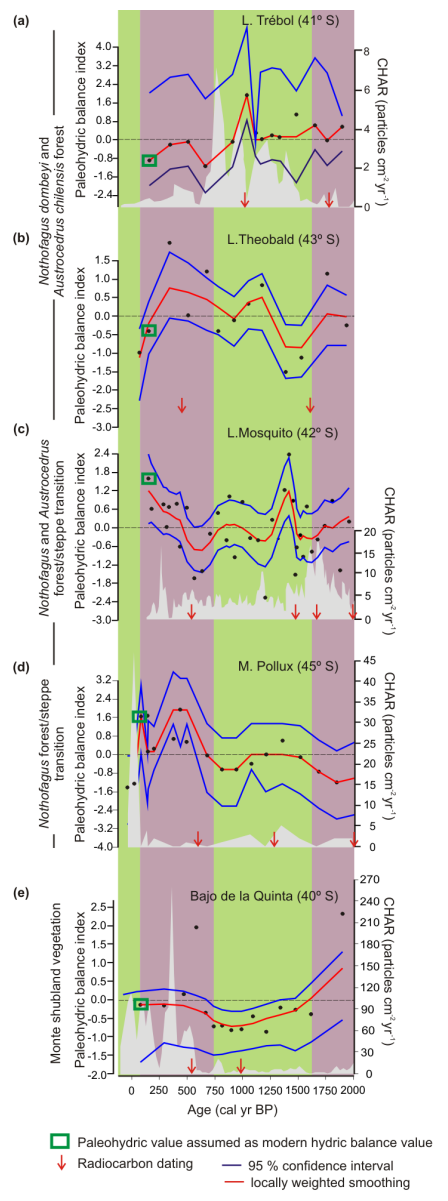

\section{CPD}

11, 2121-2157, 2015

\section{Eastern Andean environmental synthesis for the last 2000 years of \\ Patagonia}

G. D. Sottile et al.

\section{Title Page}

14

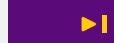

\section{Full Screen / Esc}

Printer-friendly Version

Figure 2. Northern Patagonia paleohydric balance indices. Light green area between present day and 50 cal yrBP indicates European arrival to Patagonia. 

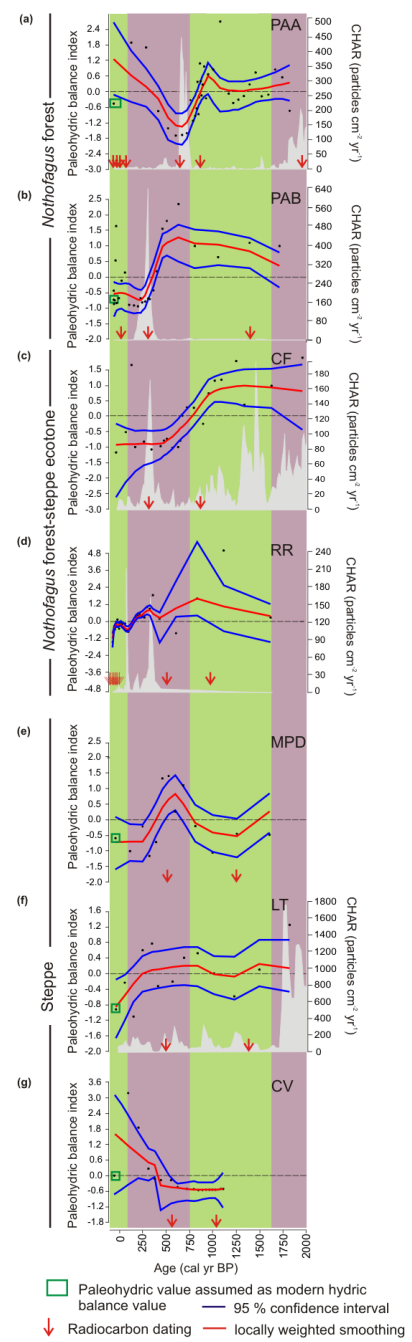

CPD

11, 2121-2157, 2015

\section{Eastern Andean} environmental synthesis for the last 2000 years of

Patagonia

G. D. Sottile et al.

\section{Title Page}

14

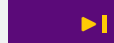

$>1$

Full Screen / Esc

Printer-friendly Version

Interactive Discussion 
Figure 3. Southern Patagonia paleohydric balance indices. Light green area between present day and 50 cal yr BP indicates European arrival to Patagonia.

\section{CPD}

$11,2121-2157,2015$

\section{Eastern Andean} environmental synthesis for the last 2000 years of

Patagonia

G. D. Sottile et al.

\section{Title Page}

Abstract

Introduction

Conclusions References

Tables

Figures

14

$>1$

Back

Full Screen / Esc

Printer-friendly Version

Interactive Discussion 


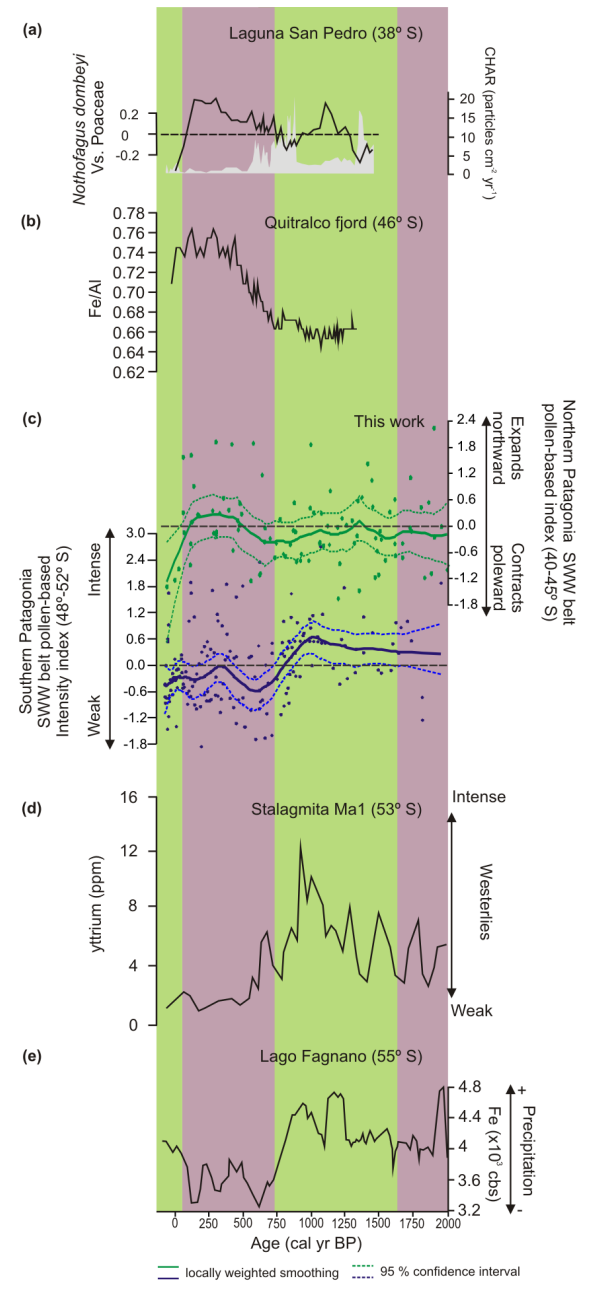

\section{CPD}

11, 2121-2157, 2015

\section{Eastern Andean environmental} synthesis for the last 2000 years of

Patagonia

G. D. Sottile et al.

\section{Title Page}

14
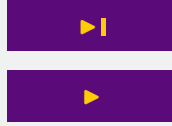

\section{Full Screen / Esc}

Printer-friendly Version

Interactive Discussion 
Figure 4. Regional synthesis with composite pollen-based Northern and Southern indices (c) and comparison to other Southern Westerly Wind belt sensitive proxy records of Patagonia: (a) Fletcher and Moreno (2012); (b) Bertrand et al. (2014); (d) Schimpf et al. (2011) and (e) Waldmann et al. (2010). Light green area between present day and 50 calyrBP indicates European arrival to Patagonia.

CPD

11, 2121-2157, 2015

\section{Eastern Andean environmental} synthesis for the last 2000 years of Patagonia

G. D. Sottile et al.

\section{Title Page}

Abstract

Introduction

Conclusions

References

Tables

Figures

14

Back

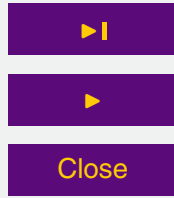

Full Screen / Esc

Printer-friendly Version

Interactive Discussion 